INEEL/EXT-99-00522

September 1999

\title{
Safety Issues with Hydrogen as a Vehicle Fuel
}

L. C. Cadwallader

J. S. Herring

LOCKHEED MARTIN 


\title{
Safety Issues with Hydrogen as a Vehicle Fuel
}

\author{
Lee C. Cadwallader \\ J. Stephen Herring
}

Published September 1999

Idaho National Engineering and Environmental Laboratory

Lockheed Martin Idaho Technologies Company

Idaho Falls, Idaho 83415-3860

Prepared for the

U.S. Department of Energy

Office of Energy Research

Under DOE Idaho Operations Office

Contract DE-AC07-94ID13223 


\begin{abstract}
This report is an initial effort to identify and evaluate safety issues associated with the use of hydrogen as a vehicle fuel in automobiles. Several forms of hydrogen have been considered: gas, liquid, slush, and hydrides. The safety issues have been discussed, beginning with properties of hydrogen and the phenomenology of hydrogen combustion. Safety-related operating experiences with hydrogen vehicles have been summarized to identify concerns that must be addressed in future design activities and to support probabilistic risk assessment. Also, applicable codes, standards, and regulations pertaining to hydrogen usage and refueling have been identified and are briefly discussed. This report serves as a safety foundation for any future hydrogen safety work, such as a safety analysis or a probabilistic risk assessment.
\end{abstract}




\section{SUMMARY}

This report is a collection of safety information and the identification of safety issues for the use of hydrogen as a transportation fuel. Several forms of hydrogen have been considered: gas, liquid, slush, and hydrides. The safety information given here includes hydrogen physical properties, a discussion of the phenomenology of hydrogen as a flammable gas, and some bounding probabilities of hydrogen combustion in spill events.

The report includes a review of safety-related operating experiences with hydrogenfueled vehicles and historical accident events involving hydrogen as a principal agent. That information is important for identification of accident initiating events, which is an initial step in probabilistic risk assessment. An initial list of events to consider for vehicles and refueling stations is given in this report. These events and other information serve as precursor data needed to perform a risk assessment of a hydrogen vehicle or refueling station.

The major safety issue is losing containment of hydrogen; as a gas it is stored under high pressure that could injure nearby personnel and as a cryogen it could cause injuries such as frostbite. The released gaseous or cryogenic hydrogen poses a combustion hazard.

There is a discussion on the applicable codes, consensus standards, and regulations pertaining to safe hydrogen usage and refueling. That discussion notes the safety precautions that must be taken and highlights noted impacts to vehicle and refueling station design generated by the safety rules and codes. There are few hydrogen-specific codes. Guidance from natural gas vehicular fuel codes is considered appropriate for assuring safety of hydrogen handling, given that hydrogen's unique properties are accounted for when following that guidance. Some of the rules were noted to conflict with each other, and the safety approach is to understand why the rule exists and choose the safest means of eliminating the hazard from the design.

Hydrogen appears to be a technically promising fuel for transportation. Testing experiences thus far have been positive. In particular, the hydrogen and fuel cell technology combination promises quiet, low emission power for automobiles, buses, industrial forklift trucks, and other vehicles. 


\section{ACKNOWLEDGMENTS}

The authors wish to thank Richard Rice and Robert Carrington for initiating and managing this program to study hydrogen fuels. Several people also supported the authors in preparation of this report: Terilyn Chenoweth for administrative details, and the technical library staff for literature searches and document procurement. 


\section{ACRONYMS}

$\begin{array}{ll}\text { AIChE } & \text { American Institute of Chemical Engineers } \\ \text { ANSI } & \text { American National Standards Institute } \\ \text { API } & \text { American Petroleum Institute } \\ \text { ASME } & \text { American Society of Mechanical Engineers } \\ \text { ASTM } & \text { American Society for Testing and Materials } \\ \text { atm } & \text { one atmosphere pressure } \\ \text { B\&PV } & \text { Boiler and pressure vessel code from ASME } \\ \text { bar } & \text { pressure equivalent to one atmosphere } \\ \text { C } & \text { Celsius temperature scale } \\ \text { CFR } & \text { US Code of Federal Regulations } \\ \text { cm } & \text { centimeter } \\ \text { DDT } & \text { deflagration to detonation transition } \\ \text { DOE } & \text { Department of Energy } \\ \text { DOT } & \text { Department of Transportation } \\ \text { EPA } & \text { Environmental Protection Agency } \\ \text { g } & \text { gram } \\ \text { K } & \text { Kelvin temperature scale } \\ \text { kg } & \text { kilogram } \\ \text { kJ } & \text { kiloJoule } \\ \text { kPa } & \text { kiloPascal } \\ \text { kW } & \text { kilowatt } \\ \text { LH2 } & \text { liquid hydrogen } \\ \text { LNG } & \text { liquefied natural gas } \\ \text { m } & \text { meter } \\ \text { mJ } & \text { milliJoule } \\ \text { mm } & \text { millimeter } \\ \text { mph } & \text { miles per hour } \\ \text { MPa } & \text { megaPascals } \\ \text { MRHT } & \text { marked rated holding time } \\ \text { NASA } & \text { National Aeronautics and Space Administration } \\ \text { NFPA } & \text { National Fire Protection Association } \\ \text { OWTT } & \text { one way travel time } \\ \text { psig } & \text { pounds per square inch, gauge } \\ \text { s } & \text { seconds } \\ \text { SRB } & \text { Solid rocket booster } \\ \text { TLV } & \text { threshold limit value } \\ \text { TNT } & \text { trinitrotoluene } \\ \text { UK } & \text { United Kingdom } \\ \text { VLHD-B } & \text { vehicle liquid hydrogen dewar, type 2 } \\ & \end{array}$




\section{TABLE OF CONTENTS}

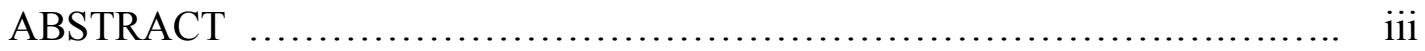

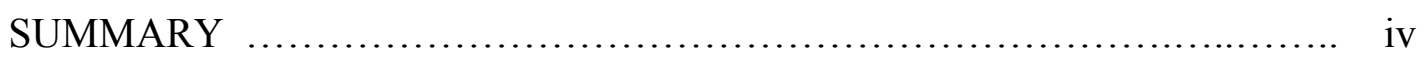

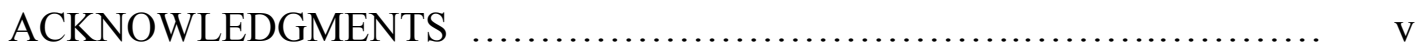

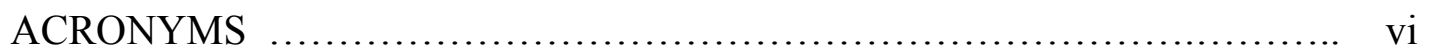

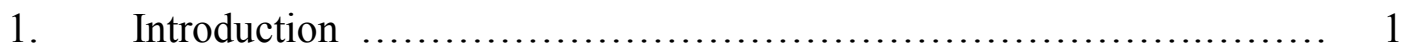

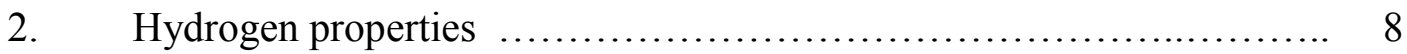

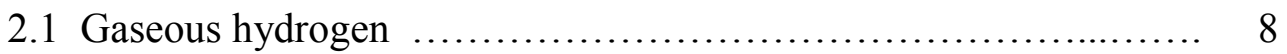

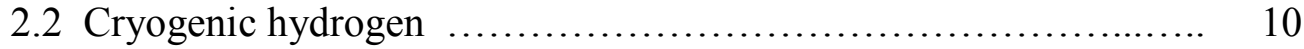

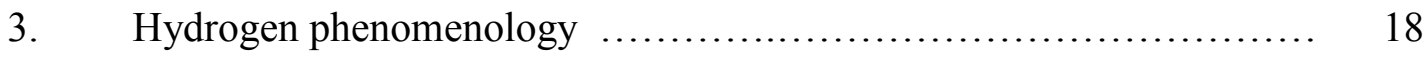

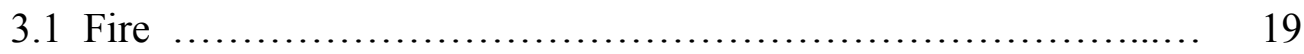

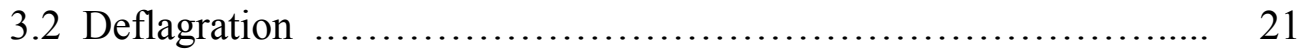

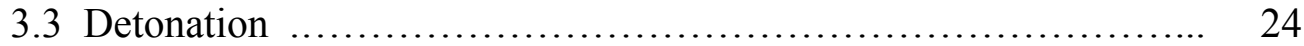

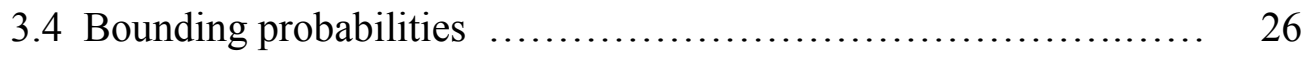

4. Hydrogen handling and operations ............................. 33

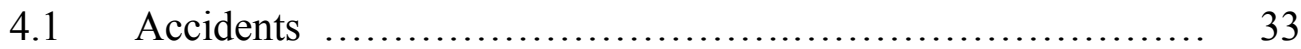

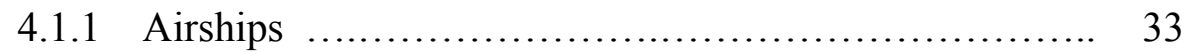

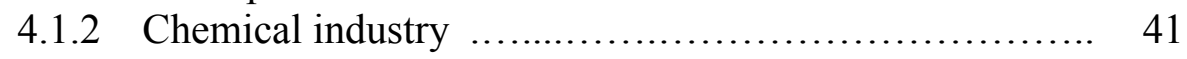

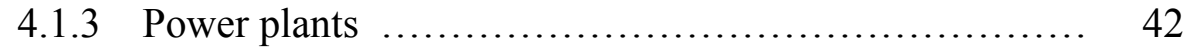

4.1.4 Aerospace operations ............................... 44

4.1 .5 DOE .............................................. 45

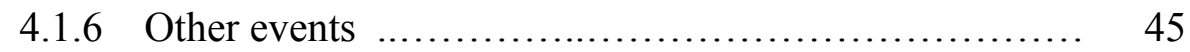

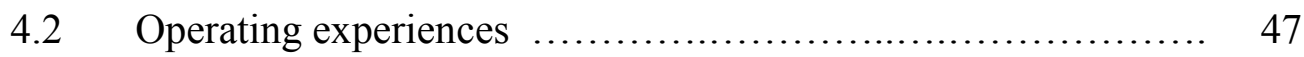

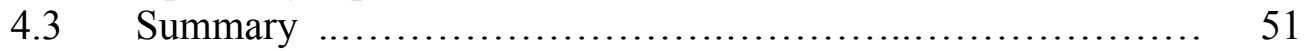

5. Codes, standards and regulations for safety $\ldots \ldots \ldots \ldots \ldots \ldots \ldots \ldots \ldots \ldots \ldots \ldots \ldots \ldots$

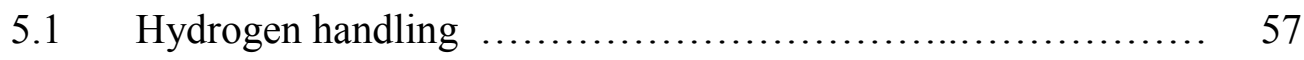

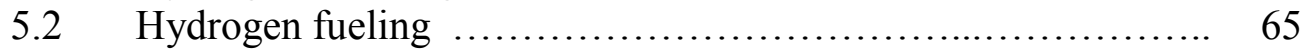

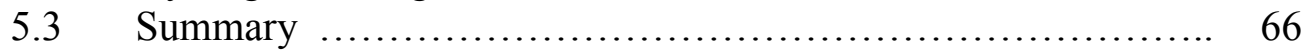

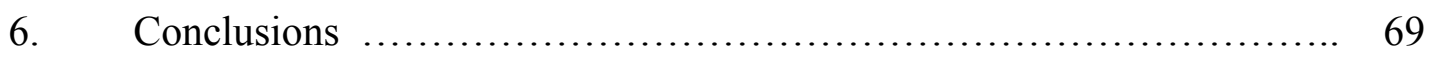




\section{TABLES}

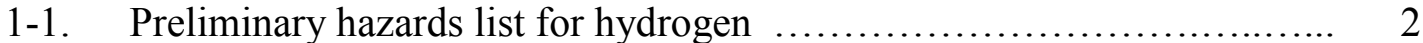

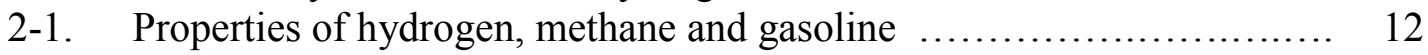

2-2. Hydrogen gas combustion properties in air at

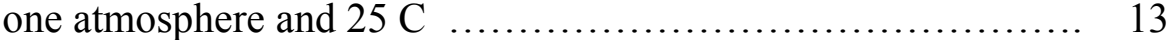

2-3. Thermophysical properties of liquid hydrogen and other cryogens ....... 13

3-1. Amounts of suppressant gases added to air

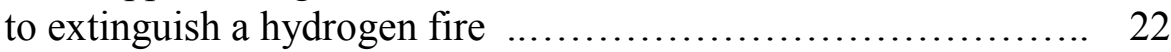

3-2. Explosion probability estimates given a flammable material release .... 28

3-3. Conditional probabilities of spills, given a transport truck accident ..... 28

3-4. Conditional probabilities of immediate ignition, given a spill .......... 28

3-5. Conditional probabilities of delayed ignition, given a spill ............ 29

4-1. Hydrogen events in US nuclear power plants through 1992 ............. 43 


\section{Safety Issues with Hydrogen as a Vehicle Fuel}

\section{INTRODUCTION}

This report summarizes safety concerns and operating experiences with hydrogen as an energy carrier material. Gaseous, liquid, and hydride hydrogen have been considered here for use as automobile fuels. Slush hydrogen is also briefly discussed. Gaseous hydrogen expands to fill available containers while liquid hydrogen can have a free surface and is considered to be a cryogenic liquid. Hydrides are chemical compounds containing hydrogen atoms, and slush hydrogen is a mixture of solid (frozen hydrogen) and liquid hydrogen. Past applications of hydrogen for automobile fuel have been to burn the hydrogen in an internal combustion engine, a gas turbine engine, a Stirling engine, or to use the gas as an input fuel for fuel cells that power an electric motor for propelling the automobile (Winter, 1988).

The National Hydrogen Association has qualitatively determined that methane is less dangerous than hydrogen, and that hydrogen is less dangerous than propane (Serfass, 1991). That assessment was based on tests of hydrogen that showed gas releases in confined spaces resulted in hydrogen being the quickest to form a burnable mixture and that hydrogen has the smallest spark minimum ignition energy, 0.02 milliJoules at stoichiometric concentration, of the three gases. In tests with a vented space, a propane release still yielded a large combustible mixture, a methane release gave a small combustible mixture, and the hydrogen release yielded virtually no combustible mixture because it easily vented from the space. Nonetheless, hydrogen ranked in the middle of the danger judgment. While this determination is useful to judge the overall risk associated with using hydrogen, there are other issues to study that will help determine the specific hazards of hydrogen storage, handling, and usage, such as unconfined releases at refueling stations or from vehicle accidents. Awareness of hazards allows design provisions to eliminate or mitigate the hazards.

A preliminary hazards list of the various forms of hydrogen for use in vehicles is given in Table 1-1. This hazards list was generated by using a list of energy types, background information on hydrogen vehicle technology (Norbeck, 1996), and analyst judgment. The qualitative list treats hydrogen gas, liquid hydrogen, slush hydrogen, organic hydrides and metallic hydrides. This hazards list will be referred to in later sections of this report.

The report gives hydrogen properties related to safety and discusses hydrogen combustion issues. Operating experiences with handling large amounts of gaseous and liquid hydrogen are summarized to assist with safety assessment and feedback to design professionals. Then applicable codes, standards, and regulations for hydrogen are identified to support compliance issues. 
Table 1-1. Preliminary hazards list for hydrogen

\begin{tabular}{|c|c|c|}
\hline \multirow{7}{*}{$\frac{\text { Form }}{\text { Gaseous hydrogen }}$} & Hazard type & Description of hazard \\
\hline & $\begin{array}{l}\text { Physical properties } \\
\text { leading to safety } \\
\text { concerns }\end{array}$ & $\begin{array}{l}\text { - Lighter than air } \\
\text {-Highly diffusive } \\
\text { - Flow-induced static charge generation } \\
\text { - Low viscosity (leaks easily) } \\
\text {-Odorless, colorless gas }\end{array}$ \\
\hline & Pressure & $\begin{array}{l}\text {-High pressure storage ( } 2000 \text { psig or } \\
\text { more) can result in pressure rupture, } \\
\text { flying debris } \\
\text { - Pipe whip concern with leak events } \\
\text { - Oxygen displacement in confined spaces } \\
\text { - Gas jet impingement damage is possible } \\
\text { - Gas jet impingement on personnel is also } \\
\text { a hazard, high pressure can cut bare skin }\end{array}$ \\
\hline & Chemical & $\begin{array}{l}\text {-Flammable, with nonluminous flame, no } \\
\text { toxic combustion products } \\
\text {-Explosive, } 4 \% \text { to } 74 \% \text { by volume } \\
\text { Can deflagrate (typically only a modest } \\
\text { overpressure, } \sim \text { a few psi in open areas) } \\
\text { Can also detonate (high overpressure } \\
\text { shock wave, } \sim \text { several atmospheres) } \\
\text { - Low ignition energy, } 0.02 \mathrm{~mJ} \text { to } 1 \mathrm{~mJ} \\
\text { spark to ignite a deflagration } \\
\text { - Modest autoignition temperature, } 574^{\circ} \mathrm{C}\end{array}$ \\
\hline & Temperature & $\begin{array}{l}\text { - Could be stored at room temperature, not } \\
\text { an issue }\end{array}$ \\
\hline & Materials issues & $\begin{array}{l}\text {-Embrittlement of metal } \\
\text {-Embrittlement of plastics }\end{array}$ \\
\hline & Toxicological & $\begin{array}{l}\text {-Asphyxiation in confined spaces } \\
\text { - No other toxic concerns }\end{array}$ \\
\hline
\end{tabular}


Table 1-1. Preliminary hazards list for hydrogen (continued)

\begin{tabular}{|c|c|c|}
\hline \multirow{7}{*}{$\frac{\text { Form }}{\text { Liquid hydrogen }}$} & Hazard type & $\begin{array}{c}\text { Description of hazard } \\
\end{array}$ \\
\hline & $\begin{array}{l}\text { Physical properties } \\
\text { leading to safety } \\
\text { concerns }\end{array}$ & $\begin{array}{l}\text { - Boiloff gas quickly warms and then is } \\
\text { lighter than air } \\
\text { - Boiloff gas is highly diffusive } \\
\text { - Flow-induced static charge generation } \\
\text { - Boiloff vent rate from storage tanks/fuel } \\
\text { tanks is typical to maintain cold } \\
\text { temperature in tank } \\
\text { - Liquid quickly, easily boils by heat } \\
\text { transfer into the } 20 \mathrm{~K} \text { liquid } \\
\text { - Rapid phase transition from liquid to gas } \\
\text { can cause pressure explosions } \\
\text { - Liquid quickly contaminates itself by } \\
\text { condensing gases from air contact } \\
\text { - Odorless, colorless, cannot easily be } \\
\text { odorized since odorants will freeze out at } \\
\text { cryogenic temperatures }\end{array}$ \\
\hline & Pressure & $\begin{array}{l}\text { - Stored under modest pressure to suppress } \\
\text { boiling (perhaps } 200 \mathrm{psig} \text { ) }\end{array}$ \\
\hline & Chemical & $\begin{array}{l}\text { Evolved gas is cold, otherwise the same } \\
\text { concerns as gaseous hydrogen }\end{array}$ \\
\hline & Temperature & $\begin{array}{l}\text { - Cryogenic burns, especially eyes } \\
\text { - Lung damage by cold vapor inhalation } \\
\text { - Possible hypothermia working near these } \\
\text { systems } \\
\text { - Condensation of air near } \mathrm{LH}_{2} \text { systems if } \\
\text { insulation allows heat leak paths; can } \\
\text { lead to oxygen rich zones near systems }\end{array}$ \\
\hline & Materials issues & $\begin{array}{l}\text { - Embrittlement of metal } \\
\text { - Mechanical stresses generated by } \\
\text { thermal contraction } \\
\text { - Mild steels susceptible to cracking at } \\
\text { cryogenic temperatures } \\
\text { - Materials have low specific heats at } \\
\text { cryogenic temperatures, easy heat } \\
\text { transfer }\end{array}$ \\
\hline & Toxicological & $\begin{array}{l}\text { - Asphyxiation in confined spaces } \\
\text { - Frostbite from acute exposure } \\
\text {-Hypothermia possible from long } \\
\text { exposure } \\
\text {-No other toxic concerns }\end{array}$ \\
\hline
\end{tabular}


Table 1-1. Preliminary hazards list for hydrogen (continued)

\begin{tabular}{|c|c|c|}
\hline \multirow{7}{*}{$\frac{\text { Form }}{\text { Slush hydrogen }}$} & Hazard type & $\begin{array}{c}\text { Description of hazard } \\
\end{array}$ \\
\hline & $\begin{array}{l}\text { Physical properties } \\
\text { leading to safety } \\
\text { concerns }\end{array}$ & $\begin{array}{l}\text { - Boiloff gas is lighter than air after } \\
\text { warming a few degrees K } \\
\text {-Boiloff gas is highly diffusive } \\
\text { - Flow-induced static charge generation } \\
\text { - Boiloff vent rate from storage tanks/fuel } \\
\text { tanks } \\
\text { - Potential for plugging by solids in slush, } \\
\text { can also lead to unexpected pressure } \\
\text { buildups } \\
\text { - Slush quickly contaminates itself by } \\
\text { condensing gases from air contact } \\
\text { - Odorless, colorless, cannot easily be } \\
\text { odorized since odorants will freeze out at } \\
\text { cryogenic temperatures }\end{array}$ \\
\hline & Pressure & - Similar to liquid hydrogen \\
\hline & Chemical & $\begin{array}{l}\text { Evolved gas is cold, otherwise the same } \\
\text { concerns as gaseous hydrogen }\end{array}$ \\
\hline & Temperature & $\begin{array}{l}\text { - Cryogenic burns, especially eyes } \\
\text { - Lung damage by cold vapor } \\
\text { - Possible hypothermia working near these } \\
\text { systems } \\
\text { - Condensation of air near } \mathrm{LH}_{2} \text { systems if } \\
\text { insulation allows heat leak paths; can } \\
\text { lead to oxygen rich zones near systems }\end{array}$ \\
\hline & Materials issues & $\begin{array}{l}\text { - Embrittlement of metal } \\
\text { - Mechanical stresses generated by } \\
\text { thermal contraction } \\
\text { - Mild steels susceptible to cracking at low } \\
\text { temperatures } \\
\text { - Materials have low specific heats at } \\
\text { cryogenic temperatures, easy heat } \\
\text { transfer }\end{array}$ \\
\hline & Toxicological & $\begin{array}{l}\text { - Asphyxiation in confined spaces } \\
\text { - Frostbite from acute exposure } \\
\text { - Hypothermia possible from long } \\
\text { exposure } \\
\text { - No other toxic concerns }\end{array}$ \\
\hline
\end{tabular}


Table 1-1. Preliminary hazards list for hydrogen (continued)

\begin{tabular}{|c|c|c|}
\hline Form & Hazard type & $\begin{array}{l}\text { Description of hazard } \\
\end{array}$ \\
\hline \multirow[t]{7}{*}{$\begin{array}{l}\text { Liquid organic } \\
\text { hydride }\end{array}$} & $\begin{array}{l}\text { Physical properties } \\
\text { leading to safety } \\
\text { concerns }\end{array}$ & $\begin{array}{l}\text {-Organics are noted for flammability, } \\
\text { sometimes toxicity (must know specific } \\
\text { chemical compound) }\end{array}$ \\
\hline & Pressure & $\begin{array}{l}\text { - Operates at low pressure, gas evolved at } \\
\text { modest pressure }\end{array}$ \\
\hline & Chemical & $\begin{array}{l}\text { - Organic carrier is probably flammable } \\
\text { - Some organics have low autoignition } \\
\text { temperatures } \\
\text {-Hydride decomposition may require } \\
\text { temperature close to hydrogen } \\
\text { autoignition temperature } \\
\text { - Thermal decomposition of organic may } \\
\text { be an issue leading to chemical exposure } \\
\text { or to burning small amounts of organic } \\
\text { in an internal combustion engine }\end{array}$ \\
\hline & Temperature & $\begin{array}{l}\text { - Heating to } 400^{\circ} \mathrm{C} \text { to evolve hydrogen } \\
\text { - Hot hydrogen gas is evolved; hot system } \\
\text { can lead to thermal burns }\end{array}$ \\
\hline & Materials issues & -Embrittlement of metal \\
\hline & Electrical & $\begin{array}{l}\text { - Heating system to initially warm hydride } \\
\text { each vehicle usage (12 VDC, low amps) } \\
\text { - Ignition source, and possible electrical } \\
\text { fire source }\end{array}$ \\
\hline & Toxicological & $\begin{array}{l}\text {-Hydrogen asphyxiation in confined } \\
\text { spaces } \\
\text {-Toxic concerns of organic carrier, } \\
\text { usually modest TLVs for occupational } \\
\text { exposure }\end{array}$ \\
\hline
\end{tabular}


Table 1-1. Preliminary hazards list for hydrogen (continued)

\begin{tabular}{|c|c|c|}
\hline Form & Hazard type & $\begin{array}{c}\text { Description of hazard } \\
\end{array}$ \\
\hline \multirow[t]{7}{*}{$\begin{array}{l}\text { Solid metallic } \\
\text { hydride }\end{array}$} & $\begin{array}{l}\text { Physical properties } \\
\text { leading to safety } \\
\text { concerns }\end{array}$ & $\begin{array}{l}\text {-Some metals are noted for } \\
\text { pyrophoricity/flammability, sometimes } \\
\text { for toxicity (need to know specific metal } \\
\text { alloy to be used in a vehicle) }\end{array}$ \\
\hline & Pressure & $\begin{array}{l}\text { - Operates for loading at room pressure or } \\
\text { higher (up to } 5 \mathrm{~atm} \text { ), gas evolved at } \\
\text { modest to high pressure (up to } 13 \mathrm{~atm} \text { ) }\end{array}$ \\
\hline & Chemical & $\begin{array}{l}\text { - Metallic carrier may be flammable or } \\
\text { pyrophoric } \\
\text { - Hydride formation is usually exothermic, } \\
\text { heat is released when fueling. See under } \\
\text { temperature. } \\
\text { - Traces of metal may be burned in the } \\
\text { internal combustion engine }\end{array}$ \\
\hline & Temperature & $\begin{array}{l}\text { - Heat to release } \mathrm{H}_{2} \text { from the metal, } \\
\text { perhaps up to } 400^{\circ} \mathrm{C} \text {; room temperature } \\
\text { storage is not a concern } \\
\text { - Hot hydrogen gas is evolved; hot system } \\
\text { can lead to thermal burns } \\
\text { - Heat released when loading } \mathrm{H}_{2} \text { onto the } \\
\text { metal, some units require active cooling. }\end{array}$ \\
\hline & Materials issues & $\begin{array}{l}\text {-Embrittlement of metal } \\
\text { - Metal oxidation } \\
\text {-May be pyrophoric in certain conditions }\end{array}$ \\
\hline & Electrical & $\begin{array}{l}\text { - Heating system to initially warm hydride } \\
\text { each vehicle usage ( } 12 \text { Volt DC, low } \\
\text { amps), uses exhaust gas heat from engine } \\
\text { during operation } \\
\text { - Ignition source, and possible electrical } \\
\text { fire source }\end{array}$ \\
\hline & Toxicological & $\begin{array}{l}\text {-Hydrogen asphyxiation in confined } \\
\text { spaces } \\
\text {-Metals such as iron and metal oxides } \\
\text { have threshold limit values (TLVs) for } \\
\text { occupational exposure }\end{array}$ \\
\hline
\end{tabular}




\section{Section 1 References}

Norbeck, 1996. J. M. Norbeck et al., editors, Hydrogen Fuel for Surface Transportation, Society of Automotive Engineers, Warrendale, Pennsylvania, 1996, ISBN 156091-684-2.

Serfass 1991. J. Serfass et al., Proceedings: Transition Strategies to Hydrogen as an Energy Carrier - First Annual Meeting of the National Hydrogen Association, EPRI GS-7248, Electric Power Research Institute, Palo Alto, CA, March 1991, paper 10 .

Winter, 1988. C. J. Winter and J. Nitsch, editors, Hydrogen as an Energy Carrier, Springer-Verlag, Berlin, 1988, ISBN 0-387-18896-7, chapter 2. 


\section{HYDROGEN PROPERTIES}

The safe handling and use of hydrogen requires an appreciation of its physical properties, both as a gaseous fuel and as stored in a liquid or adsorbed state. This chapter gives pertinent information about the physical properties of hydrogen. These properties allow calculations to be made about the safety of hydrogen usage, and comparisons to other fuels routinely used by the public.

\subsection{Gaseous hydrogen}

One of the first approaches for hydrogen usage in automobiles was the use of compressed gas storage in tanks on the automobile. The gas was burned as a hydrogen/air mixture in an internal combustion reciprocating engine. The gaseous hydrogen has been typically stored at pressures of 2,000 psig (13.9 MPa) up to 5,000 psig $(34.6 \mathrm{MPa})$ at ambient temperature, but could potentially be stored at up to 8,000 psig (55 MPa) (Norbeck, 1996). Present techniques for storing gaseous hydrogen use fiber-wound pressure tanks. A potentially promising means is of storing hydrogen gas is sorbing the gas to carbon nanotubes; heating the material to release the hydrogen (Dillon, 1997). Norbeck (1996) also mentioned storing hydrogen gas under high pressure inside glass microspheres. The gas does not diffuse rapidly through the walls of the microspheres at room temperature, but when the glass is heated, diffusion increases greatly and the hydrogen gas is released. The glass microspheres have not been developed for commercial applications thus far. Many of the systems requiring heat use the combustion product heat from the engine exhaust gases. Presumably, battery power would provide heat to release hydrogen for engine startup.

Other means to store gaseous hydrogen are adsorption onto a metal material as a hydride, or storage in an organic material as a hydride. The hydride systems operate at low pressure, but the hydriding material adds weight to the fuel storage system. Some of the metals used for hydride storage are magnesium, magnesium-nickel, iron-titanium, titanium-vanadium-manganese, lanthanum-nitride, and others (Norbeck, 1996). Ewald (1998) states that iron-titanium alloys can bind hydrogen to twice the density of compressed hydrogen gas, but impurities can reduce the storage capacity. Filling a metal hydride tank with hydrogen allows an exothermic reaction that creates heat. The heat must be removed, and the metal hydride must also be heated to release hydrogen gas. While this exothermic heat removal during fill up adds complexity to the fueling system, it also promotes safety since a tank breach will not release hydrogen without external heating to release the hydrogen (Ewald, 1998). Angus (1984) discussed that a breached hydride storage tank cools from the endothermic reaction of dehydriding. Without external heat applied, only environmental heat transfer occurs at small temperature differences, so hydrogen is released very slowly. Several liquid organic materials have been considered for hydride storage: methanol, methane, and methyl cyclohexane (Grünenfelder, 1989; Ewald, 1998). The liquid must be put under modest reforming pressure (perhaps $300 \mathrm{psig}$ ) and the reforming heat may be up to $500^{\circ} \mathrm{C}$ (Grünenfelder, 1989). Another reforming approach is producing hydrogen with plasma reforming, 
starting with hydrocarbon fuels (O’Brien, 1996). The 10,000 K plasma arc performs a partial oxidation forming hydrogen and carbon monoxide.

Gaseous hydrogen can also be used in Stirling engines and in fuel cells that power electric motors, as well as internal combustion engines. Fuel cells convert the free energy of a chemical reaction into electricity. Fuel cells considered for automobile use are either the solid polymer fuel cell (which uses a proton exchange membrane (PEM) to conduct protons) that operates at near room temperatures, or a high temperature fuel cell (from 200 to $1000^{\circ} \mathrm{C}$ ). The high temperature units under study are phosphoric acid, molten carbonate, and solid oxide fuel cells (Norbeck, 1996).

Gaseous hydrogen molecules exist in two states, about $75 \%$ are ortho-hydrogen and the remainder is para-hydrogen. Ortho-hydrogen is a state where the spins of the two hydrogen nuclei in a hydrogen molecule are in the same direction. Para-hydrogen is the state where the spins are in opposite directions (Pohl, 1995). The spin affects nuclear properties, but not hydrogen's physical or combustion properties. When the gas is liquefied, the hydrogen converts to nearly all para-hydrogen (Pohl, 1995). The ortho to para conversion is exothermic and is a factor that must be accounted for when liquefying hydrogen. Another issue with natural hydrogen is that about $0.015 \%$ by volume is deuterium, and diatomic hydrogen-deuterium is about $0.032 \%$ of natural hydrogen (Barron, 1985). Deuterium is the first isotope of hydrogen; it has a neutron in its nucleus. The properties of deuterium combustion are slightly more restrictive than those of hydrogen (Koroll, 1991), as in a slightly smaller flammability zone and slightly smaller flame speed.

Hydrogen has some important physical properties. It is the smallest atom, consisting of a proton and an electron. Hydrogen forms a diatomic molecule, $\mathrm{H}_{2}$. Molecular leakage flow rates are proportional to the square root of the inverse molecular weight, so hydrogen has a larger molecular flow rate than other gases. The molecule is very small and has been known to leak from confinement (tank, piping, etc.) even if the confinement tested as leak tight with other fluids (Bowen, 1976). This property of leaking past seals or through tiny cracks can potentially lead to gas accumulation over time in confined spaces such as a room, a vehicle passenger compartment, etc., so monitoring for hydrogen is an important safety precaution. This same property makes hydrogen much lighter than air; hydrogen easily disperses when released to the air. Hydrogen's size also means that it can diffuse through materials more easily than other gases, such as diffusing through metal pipe walls. The diffusion flow rate is usually very low (SHA, 1998).

The largest safety concern with gaseous hydrogen is its combustibility. Some unique combustion properties of hydrogen compared to other combustible materials are that hydrogen-air fires burn rapidly and do not produce smoke. There are no smoke toxicity concerns as there are with hydrocarbon-air fires (Brewer, 1978). Indeed, personnel inside a building where a hydrogen deflagration occurred suffered only bruises, ruptured eardrums (estimated 30 psig overpressure event), and some bone fractures (Reider, 1979). Smoke inhalation was not a factor in that building as it would be in explosions or fires with other materials. Hydrogen-air fires do not emit light at visible wavelengths, so they 
are non-luminous, due to a lack of carbon atoms; the flames are difficult to see in daylight and are a pale blue color at night. In contrast, hydrocarbon fires have the characteristic yellow flame color that makes their flames easy to recognize at any time. Hydrogen is non-toxic, so inhalation or other exposure is not a health threat unless the gas displaces a large quantity of atmospheric oxygen. Hydrogen leaks from highpressure containers can lead to tissue damage, because high pressure gas jets can cut a person's skin (Hammer, 1989). Compressed air for industrial cleanup is limited to 30 psig (OSHA, 1998).

Table 2-1 gives the physical properties of hydrogen and a comparison to other energy fuels. Table 2-2 gives some properties of hydrogen combustion.

\subsection{Cryogenic hydrogen}

Another means of storing hydrogen fuel on board a vehicle is as a liquid or a liquid-solid slush. Some of the 1970's work with hydrogen fuel viewed cryogenic hydrogen quite favorably because of the high weight penalties for multiple steel tanks needed for high pressure gas storage (Williamson, 1980). Recent technical advances with composite storage tanks (constructed of aluminum liners with external wraps of resin and fiberglass) (Ewald, 1998) have decreased the tank weight so that gas storage is now more competitive with liquid storage. Low pressure liquid hydrogen storage is still competitive with metal hydride storage; liquid storage with a cryogenic tank is less weight than the mass of hydride materials and their storage tanks. The engineering attractiveness of reduced weight on-board fuel storage is balanced against safety issues of handling a cryogenic fuel. Burning cryogenic gas in an internal combustion engine can be more efficient than room temperature gas because less compression work is required on the cold gas. However, the cold cryogenic gas also poses integrity concerns for engine and piping materials that experience extreme temperature fluctuations.

Two forms of cryogenic hydrogen are considered here. The first is liquid hydrogen $(20 \mathrm{~K}$ at one atmosphere), and the second is slush hydrogen (13.8 $\mathrm{K}$ at one atmosphere). Liquid hydrogen storage tanks have been used in automobiles using hydrogen fueled internal combustion engines. Slush hydrogen has some solid hydrogen included in the liquid, and has been proposed for space plane and other uses where extra fuel mass is needed. The advantage of slush hydrogen is its increased density, so there is more burnable mass per unit volume of storage tank (Pohl, 1995). The main disadvantage of slush hydrogen is its cost. Slush is produced by using a liquid helium cooled auger to freeze liquid hydrogen. Due to its high formation costs, slush hydrogen is not viewed as being an economically competitive fuel (Ewald, 1998). Since tank storage for enhanced range is not as important for an automobile as for a space plane, slush hydrogen will not be considered in detail here.

Another issue is if the naturally occurring deuterium in hydrogen will accumulate in a cryogenic fuel tank. The freezing temperature of deuterium is about $18.6 \mathrm{~K}$ (Reid, 1987),

so it is less than normal hydrogen at $20 \mathrm{~K}$. The deuterium is not expected to accumulate in a cryogenic fuel tank. 
Table 2-3 gives some physical properties of liquid hydrogen and some other cryogens. An important parameter in a spill of liquid hydrogen is its vaporization rate. Liquid hydrogen vaporization without burning depends on the thermal conductivity and heat capacity of the surface the hydrogen is spilled upon, and the weather conditions. A general range of vaporization is 2.5 to $5 \mathrm{~cm}$ of pool depth per minute (Hord, 1978). Hydrogen spill vaporization and subsequent mixing in air is extremely weather dependent, including insolation, air temperature, wind speed, wind direction, and other factors (DeVaull, 1995). 
Table 2-1. Properties of hydrogen, methane and gasoline.

\begin{tabular}{|c|c|c|c|c|}
\hline $\begin{array}{r}\text { Property } \\
\end{array}$ & Hydrogen & Methane & Gasoline & Units \\
\hline Molecular Weight & 2.016 & 16.043 & 107 & $\mathrm{amu}$ \\
\hline Triple point pressure & 0.0695 & 0.1159 & - & atm \\
\hline Triple point temperature & 13.803 & 90.68 & 180 to 220 & $\mathrm{~K}$ \\
\hline Normal boiling point (NBP) temp. & 20.268 & 11.632 & 310 to 478 & $\mathrm{~K}$ \\
\hline Critical pressure & 12.759 & 45.387 & 24.5 to 27 & atm \\
\hline Critical temperature & 32.976 & 190.56 & 540 to 569 & $\mathrm{~K}$ \\
\hline Density at critical point & 0.0314 & 0.1604 & 0.23 & $\mathrm{~g} / \mathrm{cm}^{3}$ \\
\hline Density of liquid at triple point & 0.077 & 0.4516 & - & $\mathrm{g} / \mathrm{cm}^{3}$ \\
\hline Density of solid at triple point & 0.06865 & 0.4872 & - & $\mathrm{g} / \mathrm{cm}^{3}$ \\
\hline Density of vapor at triple point & 125.597 & 251.53 & - & $\mathrm{g} / \mathrm{m}^{3}$ \\
\hline Density of liquid at NBP & 0.0708 & 0.4226 & 0.7 & $\mathrm{~g} / \mathrm{cm}^{3}$ \\
\hline Density of vapor at NBP & 0.00134 & 0.00182 & 0.0045 & $\mathrm{~g} / \mathrm{cm}^{3}$ \\
\hline Density of gas at NTP & 83.764 & 651.19 & 4400 & $\mathrm{~g} / \mathrm{m}^{3}$ \\
\hline Density ratio: NBP liquid to NTP gas & 845 & 649 & 156 & - \\
\hline Heat of fusion & 58.23 & 58.47 & 161 & $\mathrm{~J} / \mathrm{g}$ \\
\hline Heat of vaporization & 445.59 & 509.88 & 309 & $\mathrm{~J} / \mathrm{g}$ \\
\hline Heat of sublimation & 507.39 & 602.44 & - & $\mathrm{J} / \mathrm{g}$ \\
\hline Heat of combustion (low) & 119.93 & 50.02 & 44.5 & $\mathrm{~kJ} / \mathrm{g}$ \\
\hline Heat of combustion (high) & 141.86 & 55.53 & 48 & $\mathrm{~kJ} / \mathrm{g}$ \\
\hline Energy density & 8.49 & 21.14 & 31.15 & MJ/liter \\
\hline Specific heat (Cp) of NTP gas & 14.89 & 2.22 & 1.62 & $\mathrm{~J} / \mathrm{g}-\mathrm{K}$ \\
\hline Specific heat (Cp) of NBP liquid & 9.69 & 3.5 & 2.2 & $\mathrm{~J} / \mathrm{g}-\mathrm{K}$ \\
\hline Specific heat ratio $(\mathrm{Cp} / \mathrm{Cv})$ of NTP gas & 1.383 & 1.308 & 1.05 & - \\
\hline Specific heat ratio $(\mathrm{Cp} / \mathrm{Cv})$ of NBP liquid & 1.688 & 1.676 & - & - \\
\hline Viscosity of NTP gas & 0.00008 & 0.00011 & 0.000052 & $\mathrm{~g} / \mathrm{cm}-\mathrm{s}$ \\
\hline Viscosity of NBP liquid & 0.00013 & 0.00113 & 0.002 & $\mathrm{~g} / \mathrm{cm}-\mathrm{s}$ \\
\hline Thermal conductivity of NTP gas & 1.897 & 0.33 & 0.112 & $\mathrm{~mW} / \mathrm{cm}-\mathrm{K}$ \\
\hline Thermal conductivity of NBP liquid & 1 & 1.86 & 1.31 & $\mathrm{~mW} / \mathrm{cm}-\mathrm{K}$ \\
\hline Surface Tension & 0.00193 & 0.01294 & 0.0122 & $\mathrm{~N} / \mathrm{m}$ \\
\hline Dielectric constant of NTP gas & 1.00026 & 1.00079 & 1.0035 & - \\
\hline Dielectric constant of NBP liquid & 1.233 & 1.6227 & 1.93 & - \\
\hline Index of refraction of NTP gas & 1.00012 & 1.0004 & 1.0017 & - \\
\hline Index of refraction of NBP liquid & 1.11 & 1.2739 & 1.39 & - \\
\hline Adiabatic sound velocity in NTP gas & 1294 & 448 & 154 & $\mathrm{~m} / \mathrm{s}$ \\
\hline Adiabatic sound velocity in NBP liquid & 1093 & 1331 & 1155 & $\mathrm{~m} / \mathrm{s}$ \\
\hline Compressibility factor (Z) of NTP gas & 1.0006 & 1.0243 & 1.0069 & 一 \\
\hline Compressibility factor $(Z)$ in NBP liquid & 0.01712 & 0.004145 & 0.00643 & - \\
\hline Gas constant $(\mathrm{R})$ & 40.7037 & 5.11477 & 0.77 & $\mathrm{~cm}^{3}-\mathrm{atm} / \mathrm{g}-\mathrm{K}$ \\
\hline Isothermal bulk modulus of NBP liquid & 50.13 & 456.16 & 763 & $\mathrm{MN} / \mathrm{m}^{2}$ \\
\hline Volume expansivity (b) of NBP liquid & 0.01658 & 0.00346 & 0.0012 & $/ \mathrm{K}$ \\
\hline $\begin{array}{l}\text { Percentage of thermal energy radiated } \\
\text { from diffusion flame to surroundings }\end{array}$ & $17-25$ & $23-32$ & $30-42$ & percent \\
\hline \multicolumn{5}{|c|}{$\begin{array}{l}\mathrm{NTP}=1 \mathrm{~atm} \text { and } 20^{\circ} \mathrm{C}\left(293.15^{\circ} \mathrm{K}\right) \text { normal temperature and pressure } ; \mathrm{NBP}=\text { normal boiling point } \\
\text { Source: (Hord, } 1978)\end{array}$} \\
\hline
\end{tabular}


Table 2-2. Hydrogen gas combustion properties in air at one atmosphere and $25^{\circ} \mathrm{C}$

Combustion property Hydrogen deflagration Hydrogen detonation Units

Heat of reaction, high

142.5

142.5

$\mathrm{MJ} / \mathrm{kg}$

Lower flammable limit

4.1 (a)

in air

or $3.6 \mathrm{~g} / \mathrm{m}^{3}$ of air

18.3

or $16.1 \mathrm{~g} / \mathrm{m}^{3}$ of air

Volume \%

Upper flammable limit

74.0

in air

or $67 \mathrm{~g} / \mathrm{m}^{3}$ of air

59.0

or $51.8 \mathrm{~g} / \mathrm{m}^{3}$ of air

Optimum detonation

$-$

29.53

Volume \%

mixture ratio in air

(stoichiometric ratio)

Detonation maximum

$--$

1.46

$\mathrm{MPa}$

overpressure in air

Auto-ignition

574

574

${ }^{\circ} \mathrm{C}$

temperature

Minimum ignition

0.02

energy

at $29.53 \%$ (b)

Maximum flame

temperature in air

2318

$\geq 10^{7}$ (c)

$\mathrm{mJ}$

Explosion energy

$-$

2.02

2318

K

Laminar burning

velocity in air, varies

102 to 325

$--$

$(\mathrm{cm} / \mathrm{s})$

with $\mathrm{H}_{2} \%$ in air

Detonation velocity in

$--$

1.48 to 2.15

$(\mathrm{km} / \mathrm{s})$

air

Maximum overpressure

$8: 1$

$14.5: 1$

(kg TNT

per $\mathrm{m}^{3}$ of

NTP gas) ${ }^{\mathrm{d}}$

ratio

(a) For upward flame propagation; downward flame propagation is 9\% (Coward, 1952).

(b) Hydrogen spark ignition energy varies between $1 \mathrm{~mJ}$ at the ends of the flammable range down to $0.02 \mathrm{~mJ}$ at the stoichiometric concentration (Bowen, 1976).

(c) To initiate a prompt detonation in a gas-air mixture, the minimum ignition energy must be on the order of $10^{4}$ to $10^{6}$ Joules (AIChE, 1994). Under some circumstances, a hydrogen deflagration explosion can also "run up", or transition, to a detonation explosion.

(d) Theoretical maximum at stoichiometric conditions, actual value is approximately $10 \%$ of the theoretical maximum (Winter, 1988).

Sources: (Thomson, 1987), (Lewis, 1961), (Winter, 1988), (Glassman, 1987) 
Table 2-3. Thermophysical properties of liquid hydrogen and other cryogens

\begin{tabular}{|c|c|c|c|c|c|c|}
\hline Property & Hydrogen & Helium & Nitrogen & Oxygen & Methane & Units \\
\hline $\begin{array}{l}\text { Chemical } \\
\text { symbol }\end{array}$ & $\mathrm{H}_{2}$ & $\mathrm{He}$ & $\mathrm{N}_{2}$ & $\mathrm{O}_{2}$ & $\mathrm{CH}_{4}$ & -- \\
\hline $\begin{array}{l}\text { Molecular } \\
\text { weight }\end{array}$ & 2 & 4 & 28 & 32 & 16 & $\mathrm{amu}$ \\
\hline $\begin{array}{l}\text { Normal } \\
\text { boiling } \\
\text { point }\end{array}$ & $\begin{array}{c}-253 \\
(20.3)\end{array}$ & $\begin{array}{l}-269 \\
(4.2)\end{array}$ & $\begin{array}{c}-196 \\
(77.4)\end{array}$ & $\begin{array}{c}-183 \\
(90.2)\end{array}$ & $\begin{array}{c}-161 \\
(111.7)\end{array}$ & $\begin{array}{l}{ }^{\circ} \mathrm{C} \\
(\mathrm{K})\end{array}$ \\
\hline $\begin{array}{l}\text { Freezing } \\
\text { temperature }\end{array}$ & $\begin{array}{l}-259 \\
(14.1)\end{array}$ & - & $\begin{array}{c}-210 \\
(63.3)\end{array}$ & $\begin{array}{l}-219 \\
(54.8)\end{array}$ & $\begin{array}{l}-183 \\
(90.6)\end{array}$ & $\begin{array}{l}{ }^{\circ} \mathrm{C} \\
(\mathrm{K})\end{array}$ \\
\hline $\begin{array}{l}\text { Critical } \\
\text { pressure }\end{array}$ & 13.4 & 2.3 & 34.5 & 51.4 & 47 & atm \\
\hline $\begin{array}{l}\text { Liquid to } \\
\text { Gas } \\
\text { Expansion } \\
\text { Boiloff } \\
\text { Ratio at } \\
1 \text { atm and } \\
15^{\circ} \mathrm{C}\end{array}$ & 826 & 738 & 678 & 843 & 626 & -- \\
\hline $\begin{array}{l}\text { Density of } \\
\text { Saturated } \\
\text { Liquid at } \\
\text { one } \\
\text { atmosphere }\end{array}$ & 70 & 125 & 804 & 1142 & 424 & $\mathrm{~kg} / \mathrm{m}^{3}$ \\
\hline $\begin{array}{l}\text { Gas density } \\
\text { relative to } \\
\text { air }(1.21 \\
\left.\mathrm{kg} / \mathrm{m}^{3}\right) \text { at } \\
1 \mathrm{~atm} \text { and } \\
15^{\circ} \mathrm{C}\end{array}$ & 0.07 & 0.14 & 0.98 & 1.12 & 0.56 & -- \\
\hline $\begin{array}{l}\text { Fire / } \\
\text { explosion } \\
\text { hazard }\end{array}$ & flammable & no & no & yes & flammable & -- \\
\hline $\begin{array}{l}\text { Hazard of } \\
\text { cryogenic } \\
\text { temperature } \\
\text { liquefying } \\
\text { nearby air }\end{array}$ & yes & yes & yes & no & no & -- \\
\hline
\end{tabular}




\section{Section 2 References}

AIChE, 1994. Guidelines for Evaluating the Characteristics of Vapor Cloud Explosions, Flash Fires, and BLEVEs, American Institute of Chemical Engineers, Center for Chemical Process Safety, New York, 1994, ISBN 0-8169-0474-X, chapter 3.

Angus, 1984. H. C. Angus, "Storage, Distribution and Compression of Hydrogen," Chemistry and Industry, January 16, 1984, pages 68-72.

Barron, 1985. R. F. Barron, Cryogenic Systems, second edition, Oxford University Press ,New York, 1985, chapter 4.

BCC, 1991. British Cryogenics Council, Cryogenics Safety Manual, A Guide to Good Practice, third edition, Butterworth Hienemann, Oxford, UK, 1991, chapter 4.

Bowen, 1976. T. L. Bowen, "Hazards Associated with Hydrogen Fuel," Proceedings of the $11^{\text {th }}$ Intersociety Energy Conversion Engineering Conference, State Line, Nevada, September 12-17, 1976, pages 997-1002.

Brewer, 1978. G. D. Brewer, "Some Environmental and Safety Aspects of Using Hydrogen as a Fuel," International Journal of Hydrogen Energy, $\underline{3}$, 1978, pages 461-474.

Coward, 1952. H. F. Coward and G. W. Jones, Limits of Flammability of Gases and Vapors, Bureau of Mines Bulletin 503, US Government Printing Office, Washington, DC, 1952.

DeVaull, 1995. G. E. DeVaull et al., Understanding Atmospheric Dispersion of Accidental Releases, Center for Chemical Process Safety, AIChE, New York, 1995, ISBN 0-8169-0681-5, chapter 2.

Dillon, 1997. A. C. Dillon et al., "Storage of Hydrogen in Single-Walled Carbon Nanotubes," Nature, 386 (number 6623), March 27, 1997, pages 377-379.

Ewald, 1998. R. Ewald, "Requirements for Advanced Mobile Storage Systems," International Journal of Hydrogen Energy, 23, 1998, pages 803-814.

Glassman, 1987. I. Glassman, Combustion, second edition, Academic Press, Orlando, Florida, 1987, ISBN 0-12-285851-4, appendix D.

Grünenfelder, 1989. N. F. Grünenfelder and Th. H. Schucan, "Seasonal Storage of Hydrogen in Liquid Organic Hydrides: Description of the Second Prototype Vehicle," International Journal of Hydrogen Energy, 14, 1989, pages 579-586. 
Hammer, 1989. W. Hammer, Occupational Safety Management and Engineering, fourth edition, Prentice Hall, Englewood Cliffs, New Jersey, 1989, ISBN 0-13-6293794, chapter 19.

Hord, 1978. J. Hord, "Is Hydrogen a Safe Fuel?," International Journal of Hydrogen Energy, $\underline{3}, 1978$, pages 157-176.

Koroll, 1991. G. W. Koroll and R. K. Kumar, "Isotope Effects on the Combustion Properties of Deuterium and Hydrogen," Combustion and Flame, $\underline{84}$, 1991, pp. 154-159.

Lewis, 1961. B. Lewis and G. von Elbe, Combustion, Flames and Explosions of Gases, second edition, Academic Press, New York, 1961, chapter V, section 13.

Norbeck, 1996. J. M. Norbeck et al., editors, Hydrogen Fuel for Surface Transportation, Society of Automotive Engineers, Warrendale, Pennsylvania, 1996, ISBN 156091-684-2, chapter 2.

O’Brien, 1996. C. J. O'Brien et al., "Hydrogen Production via Plasma Reformers," Proceedings of the $31^{\text {st }}$ Intersociety Energy Conversion Engineering Conference, Washington, DC, August 11-16, 1996, volume 3, Institute of Electrical and Electronics Engineers, pages 1747-1752.

OSHA, 1998. Title 29, Labor, of the Code of Federal Regulations, Part 1910.242, July 1, 1998.

Pohl, 1995. H. W. Pohl, editor, Hydrogen and Other Alternative Fuels for Air and Ground Transportation, John Wiley \& Sons, Chichester, UK, 1995, ISBN 0-47195336-9, chapter 6 .

Reid, 1987. R. C. Reid et al., The Properties of Gases and Liquids, fourth edition, McGraw-Hill, Inc., New York, 1987, Appendix A, page 661.

Reider, 1979. R. Reider and F. J. Edeskuty, "Hydrogen Safety Problems," International Journal of Hydrogen Energy, 4, 1979, pages 41-45.

SHA, 1998. Sourcebook for Hydrogen Applications, published by the Hydrogen Research Institute and the National Renewable Energy Laboratory, distributed by Tektrend International, Quebec, CA, 1998.

Thomson, 1987. J. R. Thomson, Engineering Safety Assessment, An Introduction, Longman Scientific \& Technical, Essex, England, 1987, ISBN 0-582-41630-2, chapter 5 . 
Williamson, 1980. K. D. Williamson, Jr., "Prospective Use of Liquid Hydrogen as a Fuel for Transportation," Proceedings of the Eighth International Cryogenic Engineering Conference (ICEC8), Genova, Italy, 3-6 June 1980, IPC Science and Technology Press, Surrey, England, 1980, pages 290-302.

Winter, 1988. C.-J. Winter and J. Nitsch, editors, Hydrogen as an Energy Carrier, technologies, systems, economy, Springer-Verlag, Berlin, 1988, ISBN 0-387818896-7, chapter 4. 


\section{HYDROGEN PHENOMENOLOGY}

This chapter gives information about hydrogen combustion. Hydrogen gas poses threats to personnel and the public due to its combustibility and its potential for displacing oxygen in confined areas. Confined areas associated with automobiles themselves could be the passenger compartment, trunk or other cargo area, or engine compartment. Other confined areas common to automobiles could be a repair garage bay, a tire servicing bay, a parking garage, a residential garage or protective structure, a car wash building, etc. Explosion confinement areas could be a narrow street between tall buildings, a tunnel, under a bridge, underground parking garage, etc. Liquefied hydrogen has similar concerns of combustibility and oxygen displacement because it easily boils when released to air. Liquefied hydrogen has the additional concern of extremely cold temperatures that can lead to cryogenic burns, frostbite, hypothermia, and lung damage from inhalation of cold vapor. The eyes are a special concern for tissue damage from cryogen contact. Cryogen contact can also fail mild steel due to ductile-to-brittle transition and thermal contraction at low temperatures.

The subject of gas combustion can be complex. Hydrogen gas can burn in a flame, like a candle flame, when it has not been well mixed in a large volume of air. Flames like candle flames are called diffusion flames since the oxygen from air and fuel molecules diffuse to mingle with each other in the combustion zone (the approximately $1 \mathrm{~mm}$ thick edge of the candle flame) (Drysdale, 1985). A hydrogen flame can occur when hydrogen is released from pressurized storage. The hydrogen may exit a leak location in a pressurized stream, or jet. The jet will have air at its edges and can combust in a jet flame, which is another name for a diffusion flame. A jet flame is similar to a Bunsen burner flame. Hydrogen gas can also experience a "flash fire" as it is mixing in air. A flash fire is a combustion event with little or no overpressure, and, as the name implies, it proceeds in a very fast time scale until the hydrogen is consumed. As hydrogen gas is released into air, typically its concentration is very high near the release point and it is not well mixed in the air. If the gas ignites at that time, generally the result is a flash fire. Flash fires consume escaping hydrogen so it is not available for further mixing in air. The hydrogen combusts into water vapor. While a flash fire appears to be a rapid event, the burning velocity is at the laminar value (AIChE, 1994). The burning velocity varies between 102 and $346 \mathrm{~cm} / \mathrm{s}$, depending on the hydrogen concentration in the air (see Chapter 2).

The other means of combustion is when the hydrogen is well dispersed, or mixed, in air. Dispersing the fuel gas into air is called a 'pre-mixed' system (Drysdale, 1985). Processes besides molecular diffusion, such as buoyant dispersion, turbulent mixing by wind, and jet entrainment, work to mix the hydrogen in air. When the hydrogen gas has been well mixed with air, as in a gas cloud release into the air, the gas can have a deflagration explosion or a detonation explosion. Of these two pre-mixed combustion reactions, a deflagration explosion is less severe than a detonation explosion. The detonation has much higher overpressure, a shock wave, and much higher heat energy release than a deflagration. A deflagration explosion is the more likely event in an open gas cloud since the minimum volume concentration mixture to allow a deflagration is 
low, $4 \%$ in air for upward burning, and the minimum ignition energy is small, about $1 \mathrm{~mJ}$ at $4 \%$ concentration (see Chapter 2). Igniting a detonation in a gas cloud is more difficult, since the minimum volume concentration is $18.3 \%$ in air and the ignition energy is in the $10 \mathrm{~kJ}$ range. In general, such strong, that is; high energy, ignitors are recognized and controlled, so initiating a detonation in a hydrogen cloud is not as likely as initiating a deflagration. Hydrogen has one other important characteristic that differs from other combustible gases; it has a very high flame speed. It is possible to ignite a deflagration that can "run up" or transition to a detonation. To achieve a deflagration to detonation transition (DDT), the hydrogen cloud must have a high concentration (over 18\%) in air and there must be some form of combustion wave pressure reflection (such as an enclosure wall) that will build pressure to drive the combustion speed above sonic velocity in air (over $350 \mathrm{~m} / \mathrm{s}$ ).

Deflagration explosions are less severe than detonations, but are still important to safety because even modest overpressures of a few psig and heat energy releases can harm people in the vicinity and can damage buildings, exposed equipment, and the environment. A deflagration can propel debris that can cause damage, and it can ignite secondary fires in the blast damage area. A detonation explosion can be more severe. A detonation blast pressure wave can injure people so severely that they perish. The blast wave can collapse building walls around its radius, which often leads to collapse of entire buildings. A detonation blast wave can damage a much larger area than a deflagration overpressure wave. Debris propelled by the detonation blast wave (generally referred to as missiles) create damage by impacting people or structures. As with a deflagration, secondary fires can be ignited from heat transferred to the debris generated by the pressure wave.

\subsection{Fire}

A fire is a non-explosion fuel-oxygen combustion event. In a fire, the combustion wave front (the flame) can be relatively stationary with the combustible material and air diffusing into the combustion zone. This is called a diffusion flame because the oxygen from air and combustible material mingle by slow-paced molecular diffusion processes in the combustion zone (i.e., the edge of the flame). The flame of a fire produces the same combustion energy as a deflagration event, but has a slower energy release rate than a deflagration. A typical fire can still threaten personnel safety by smoke inhalation and heat exposure, and a fire can create property damage or destruction. However, hydrogenair mixtures burn without any smoke, so smoke inhalation is only a concern if the fire ignites other materials. Inhalation of hot combustion products from hydrogen-air reactions and fire heat exposure are important since they can damage a person's lungs and burn the skin. Another effect of a hydrogen fire would be the condensation of steam. Water vapor, such as humidity in air, will be heated by the fire and then condense on nearby cooler objects. The steam condensation could lead to burns. Hydrogen fires can also be jet fires, that is, a diffusion flame fed by a jet of hydrogen leaking from a pressurized container, or flash fires, which burn through a typically rich concentration hydrogen cloud in air but do not generate any appreciable overpressures like deflagrations. 
In a gaseous hydrogen release event, the gas would typically release at pressures above atmospheric. At the release point, the hydrogen concentration is $100 \%$ hydrogen, too rich for a combustion reaction. The gas jet will cause some air entrainment, and the gas at the outer edges of the jet will also slow from momentum exchange and begin to mix with entrained air. The slowing hydrogen and entrained air can form a burnable mixture because of hydrogen's very wide flammable range. Hydrogen also has among the lowest ignition energies, and the NFPA (1991) suggests that the static electricity generated by the flow of pressurized hydrogen gas is large enough to cause a discharge to ground. This effect has occurred in hydrogen venting situations (Edeskuty, 1996). The electrical discharge is more than the one-milliJoule energy required to ignite the hydrogen-oxygen in the edges of the jet. As the flame burns, heating from the flame may cause greater jet turbulence, which will allow more air mixing and more flaming combustion. The NFPA (1991) states that there is rarely a "no fire" gas cloud release scenario with hydrogen; either the gas cloud ignites, or it quickly rises and disperses to concentrations below the lower flammable limit.

If a hydrogen system were operated for some reason at subatmospheric pressure, there would be a concern that a system breach could draw in atmospheric air, so that air and hydrogen were mingling inside the confinement of system piping, tanks, and other equipment. This air admission poses a concern since flowing gas might create enough electrostatic charge to ignite hydrogen, and deflagration overpressures are more damaging within confinement. Within confinement there is also a greater chance for transition to the high overpressure detonation event. Bodurtha (1980) stated that if the length-to-diameter ratio of a pipe or vessel were more than 10, a detonation could occur. Some examples of air mingling with hydrogen in a hydrogen-powered automobile might be: a nearly empty liquid hydrogen tank that suffers an air inleakage (if the tank is warm enough to not condense the air), filling hydrogen into a tank that has not been purged of air, or air backflow into a hydrogen-rich atmosphere of the exhaust system of an internal combustion engine that is missing its cylinder firings.

In one viewpoint, a hydrogen jet fire can be beneficial. If the area around the leak is confining (that is, within a building, a tunnel, a viaduct, a trench, a valley, etc.), then the jet fire reacts the hydrogen and does not allow hydrogen to pre-mix in the confined space. Without a pre-mixed system, an explosion cannot occur. Extinguishing the jet fire without isolating the hydrogen supply leads to venting unburned hydrogen. The hydrogen could accumulate and result in formation of an explosive mixture. The burning gas also marks its fuel location, although the flame of hydrogen is typically non-luminous unless some sort of carbon-based fuel is included in the combustion flames. Vervalin (1985) states that workmen at chemical plants have walked directly into hydrogen flames since these are very hard to see. Means to detect a flame exist, from the fire service's simple expedient of holding a broom out and tossing dirt ahead of the advancing fire fighters, to more sophisticated methods. The broom is used so that when its bristles begin to burn the edge of the fire is located, and the combustibles in dirt will incandesce when they reach the edge of the fire (NFPA 1991). More sophisticated means include infrared and ultraviolet detectors. 
Fire fighters are trained to stop the flow of hydrogen if possible (Friedman, 1998; DOT, 1996; NASA, 1968). The fire fighters may use isolation valves or other means. They will simultaneously cool the gaseous hydrogen tank to reduce its pressure, thereby reducing the leakage flow rate and as the fuel gas cools it requires somewhat more heat energy to burn. If the tank is cryogenic, they will cool the tank exterior to room temperature so that there is no added heat load to the tank cryogenic insulation, and - if feasible in the situation - they may turn the tank so that vapor is released from a breach rather than liquid. Liquid releases boil and produce roughly 800 times their volume in vapor, so releasing vapor is less mass to deal with than releasing the liquid. Keeping the liquid as cool as possible by cooling the tank exterior reduces the rate of vapor emission. Also, vapor disperses more easily than liquid, and liquid cryogen pooling on the ground is a safety threat to the fire fighters and a structural failure threat to any nearby ductile-tobrittle-transition materials, such as mild steels. The liquid cryogen may also seek low levels, such as sewers, drain pipes, or other low lying, semi-confined areas. Vapor released from a tank can be diverted with water sprays that the fire fighters readily deploy, but liquids would typically require some sort of dike or dam to divert the direction of flow. The next step that fire fighters take is to cool surrounding equipment and structures to prevent fire spread by radiant heating (Friedman, 1998; DOT, 1996). While hydrogen convects much of its combustion heat away, there is enough radiation heating to present a fire spread problem. Small hydrogen fires can be extinguished with dry chemical or carbon dioxide by applying the agent to the base of the flame and in the direction of the flame so that the material is drawn into the gas bag of the flame. Large hydrogen fires can be controlled or extinguished using water spray or fog. Cooling the surrounding materials is important not only to limit fire spread, but also to assure that any unburned hydrogen is not reignited by hot substances nearby. The fire fighting equipment should be grounded to preclude any sparking.

Fire fighters can also use steam, halon, nitrogen, or carbon dioxide to extinguish the hydrogen flames. They will attack the base of the flame and aim streams of these suppressants along the same direction as the flame to entrain these suppressants into the flame (Friedman, 1998). Table 3-1 gives some volume mixtures of some suppressant gases needed to extinguish a hydrogen-air fire.

\subsection{Deflagration}

A deflagration explosion is also a combustion event, where the combustion wave front is subsonic in the unreacted medium (typically air ahead of the wave front). The sound speed in air at normal temperature and pressure is $350 \mathrm{~m} / \mathrm{s}$. For gas deflagrations, the combustible material and the oxidizing agent (oxygen in air) are pre-mixed; that is, well dispersed and mingling together. This mixing assures adequate oxygen to hydrogen fuel ratios for combustion. The entire flammable zone, between $4 \%$ and $75 \%$ concentration of hydrogen in air, can support a deflagration event. A deflagration is typically a modest time scale and modest energy release event. A gas cloud deflagration might take up to seconds to combust, and the resulting overpressures rarely exceed eight times the initial pressure (Porter, 1972; Edeskuty, 1986) and are generally very much below that high value. 
Table 3-1. Amounts of suppressant gases added to air to extinguish a hydrogen fire

\begin{tabular}{|c|c|c|c|}
\hline \multirow{2}{*}{ Suppressant gas } & \multicolumn{3}{|c|}{ Combustible gas } \\
\hline & Hydrogen & Propane & Methane \\
\hline & \multicolumn{3}{|c|}{$\begin{array}{l}\text { Values listed in volume parts of suppressant gas needed per } 100 \\
\text { volume parts of air }\end{array}$} \\
\hline Halon $1301\left(\mathrm{CF}_{3} \mathrm{Br}\right)$ & 46 & 4.3 & 3.1 \\
\hline $\begin{array}{l}\text { Halon } 1211 \\
\left(\mathrm{CF}_{2} \mathrm{ClBr}\right)\end{array}$ & 60 & 4.8 & 3.2 \\
\hline Carbon dioxide & 156 & 41 & 32 \\
\hline Water vapor (steam) & 181 & -- & 41 \\
\hline Nitrogen & 313 & 76 & 66 \\
\hline Helium & -- & -- & 102 \\
\hline \multicolumn{4}{|c|}{$\begin{array}{l}\text { Source: Friedman (1998) } \\
\text { Note: In some cases, a somewhat lower concentration of inert gas than is necessary to } \\
\text { ensure suppression can be adequate to cause the flame to detach itself from the } \\
\text { combustible gas exit location. This detachment is called "lift off" or "blow off". The } \\
\text { diffusion flames are distorted by the inrushing suppressant gas, making the combustion } \\
\text { reaction zone on the flame surface thinner; the fuel vapor has less time to diffuse and } \\
\text { chemically react in the thinner zone. The combustion reactions become incomplete and } \\
\text { the flame cools past its sustainable level (typically less than } 1600^{\circ} \mathrm{K} \text { [the hydrogen flame } \\
\left.\text { temperature is } 2318^{\circ} \mathrm{K}\right] \text { ). The flame extinguishes itself under those conditions (Drysdale, } \\
\text { 1985). }\end{array}$} \\
\hline
\end{tabular}


An important issue with hydrogen deflagration is that hydrogen has a high flame speed. The flame speed is not a synonym for the burning velocity. The fundamental burning velocity is the rate at which a plane combustion wave will propagate into an infinitely large, stationary, quiescent flammable mixture (Drysdale, 1985). The burning velocity changes with changing concentrations of hydrogen; the velocity is $255 \mathrm{~cm} / \mathrm{s}$ at stoichiometric conditions in air, and the maximum velocity occurs at a $40.1 \%$ hydrogen concentration in air (France, 1980). The flame speed is a measure of the rate at which a flame will travel with respect to a fixed observer. The flame speed is generally much greater than the burning velocity because the flammable mixture of gases just ahead of the flame front (the combustion wave) is pushed by the expansion of burnt gases, the combustion products coming from the combustion wave (Drysdale, 1985). The burning velocity and the flame speed will increase with increasing temperature of the gas mixture, with increasing pressure, and generally with increasing concentration. The burning velocity maximizes for gas mixtures slightly fuel rich of the stoichiometric concentration. The stoichiometric concentration is the perfect proportions of oxygen (that is, air) and combustible gas for the most complete combustion event with no residual reactants remaining. For hydrogen in air, the stoichiometric concentration is $29.5 \%$ (see Table 22). Often in explosion modeling work, the stoichiometric concentration is chosen as the basis for energy release since this complete combustion value gives the maximum energy output, so the gas cloud explosion is bounded by the worst consequence event. In reality, many gas cloud explosions result from mixtures much leaner than stoichiometric, and their combustion is incomplete. The overpressure generated is substantially below the theoretical maximum. For lean hydrogen mixtures (below 8\% volume concentration) ignited in a confined test chamber, the pressure ratios are much less than $8: 1$, more in the range from 1.4:1 up to 3:1 (Edeskuty, 1986). Lean concentration deflagrations in open air can be expected to produce less overpressure than in confined chambers.

Deflagrations are much more likely than detonations because the flammable range is broader, as mentioned above, and the spark ignition energy is much lower for a deflagration. For a given release, the broad concentration range permits a cloud to spread out while still keeping a concentration within the deflagration limits. As a gas cloud spreads further, the likelihood that it can encounter an ignition source becomes greater. Of course, the edges of a gas cloud are usually at low concentration of hydrogen since mixing in air is occurring most strongly at the edges of the cloud. An ignitor, either weak $(\leq 1 \mathrm{~mJ})$ or strong $(>10 \mathrm{~kJ})$ at a hydrogen concentration of less than $18.3 \%$ can only initiate a deflagration, unless special circumstances such as shock wave reflection have reduced this value slightly. Some gases, such as acetylene and gasoline vapors, have their detonation limits at, or much closer to, the lower flammable limit. In that respect, hydrogen has an inherent safety characteristic.

Deflagrations can undergo a transition to detonation under conditions where the combustion wave is increased past the sonic velocity in the unreacted medium. Factors that affect the possibility of a deflagration to detonation transition (DDT) in hydrogen are the hydrogen concentration (the gas concentration detonation range is $18-59 \%$ ), the 
degree of confinement of the gas, the presence of obstacles or conditions that promote turbulence in the burning gas, and the strength of the ignition source (Edeskuty, 1986). Other factors include weather conditions, such as humidity, wind, and atmospheric inversions that might partially reflect a combustion wave back toward the earth. Most researchers agree that an unconfined, open air hydrogen deflagration cannot transition to a detonation without having had a strong ignitor, a sufficiently large cloud for the combustion wave to accelerate through, and some form of turbulence induced by obstacles or other perturbation in the combustion wave (Cassutt, 1959; Eichert, 1986; Edeskuty, 1988; Lees, 1996; Pitblado, 1996).

Fire fighters may arrive at a facility before a deflagration event occurs since typically minutes to hours are needed for gas mixing in air. In that case, they can attempt to move or disperse a gas cloud with water sprays, isolate the hydrogen leak, and perhaps remove potential ignition sources (such as isolating electrical power in the vicinity). If they do not arrive before a deflagration occurs, then the most important actions are to render first aid to any injured persons, extinguish any secondary fires ignited by the deflagration, and to perform rescue/extrication or other amelioration actions.

\subsection{Detonation}

A detonation is also a combustion event, where the combustion wave front is supersonic in the unreacted medium. A detonation is typically a fast time scale event with high energy output. A combustible gas detonation is also pre-mixed, like the deflagration. In chapter 2, information about the lower and upper limits for detonation were given to be 18.3 and $59 \%$ in air. A detonation requires a high energy ignitor, $10 \mathrm{~kJ}$ or more, that produces a blast wave and enough energy to keep the post-blast wave temperature above the autoignition temperature for the mixture (AIChE, 1994). The theoretical maximum overpressure obtainable from a gas cloud detonation of hydrogen is 14.5 atmospheres, if a 1 atmosphere gas cloud was directly ignited. The US Environmental Protection Agency (EPA) gives direction (CFR, 1998) that when analyzing an explosion of a flammable gas cloud from a stationary facility, "The owner or operator shall assume that the quantity of the flammable substance ... vaporizes resulting in a vapor cloud explosion. A yield factor of 10 percent of the available energy released in the explosion shall be used to determine the distance to the explosion endpoint ( 1 psig) if the model used is based on trinitrotoluene (TNT)-equivalent methods." The worst case release shall assume a wind speed of $1.5 \mathrm{~m} / \mathrm{s}$ and an atmospheric stability class F. The air temperature and humidity can be the highest temperature and average humidity recorded in the previous three years for the site, or $25^{\circ} \mathrm{C}$ and $50 \%$ humidity as default values. A ground level release must be assumed, accounting for surface roughness [urban or rural] and gas buoyancy. The release temperature shall be the process or ambient temperature, whichever is most appropriate. The 1 psig blast wave pressure endpoint can shatter windows, damage houses, and knock a person down (Brauer, 1994), but it is generally not thought to be fatal. No debilitating effects, such as ear drum rupture, lung damage, etc., are seen at 1 psig overpressure. 
An important issue with deflagration to detonation transition is the maximum overpressure that could be obtained. With a deflagration initiated at atmospheric pressure, the theoretical maximum overpressure is 8 atmospheres (see Table 2-2) and it is usually much less than that. For a DDT, the beginning pressure is the deflagration pressure, not atmospheric pressure. Therefore, DDT maximum obtainable overpressure can be higher than the detonation pressure maximum of 14.5 atmospheres. Fortunately, most authors agree that even though hydrogen has a high flame speed and consequently high overpressures from deflagrations, a transition to detonation is not possible in an unconfined area (Edeskuty, 1988). Some form of combustion front reflection or turbulence created by obstacles is needed to increase the flame speed past sonic velocity, and the hydrogen concentration must be in the detonation region (18 to 59\%) to obtain a transition, although some authors have experimental results that indicate lower values, down to $11 \%$, for the lower explosive limit under certain conditions (Ciccarelli, 1998). Since turbulence is required, the difference between the lower flammable and lower explosive limits exists for hydrogen, and ignition energies for deflagrations are small, deflagrations are considered to be much more likely than detonation events, making deflagrations the safety significant events.

A vapor cloud explosion is a difficult phenomenon to model. Approaches have varied from simple hazard zone estimation (i.e., the Mond Index and Dow Index) and TNTequivalent estimation (see AIChE, 1994), then multi-energy source models (Van den Berg, 1985), and finally the complex modeling that uses three dimensional computational fluid dynamic models of gas spread (Popat, 1996). The TNT-equivalent model is often used in hazard analysis (Deshotels, 1995). This method ratios the heat of combustion of the vapor cloud material to TNT, using an appropriate yield factor. Damage is the based on the calculated TNT quantity acting from the center of the cloud. TNT and vapor clouds have differing explosion characteristics, but the approximation can be adequate for hazard assessment.

An interesting and important characteristic of detonation shock waves is the formation of the detonation cell. A cell is a physical volume formed by the shock waves traveling through the unreacted medium. Shock waves reflect off of objects in their path, such as the ground, temperature strata in the air, hills, and obstacles (building walls, pipework, structures, etc.). Reflected shock waves generally move transverse to the primary shock wave front and interact with it, forming what are called Mach stem shock waves. A detonation cell boundary is the shock wave front, the reflected (transverse) shock waves, and the Mach stems. Experiments where detonation waves passed along the side of metal foils (that had been 'smoked' to leave soot on the foil surface) revealed patterns left by the detonation shock waves. The shock waves moved the soot into regular patterns that have been called cells (Strehlow, 1971); the two dimensional cell pattern is sometimes referred to as "fish scales." Each cell is roughly rhomboid-shaped. The characteristic dimension of a cell is its longest axial distance. The cell size varies with the concentration of the reactants, it is about $1.5 \mathrm{~cm}$ for a stoichiometric hydrogen-air mixture, and increases to about 1 meter for the limits (18 and 59\%) of the detonation range (Guirao, 1989). The cell size is a parameter that can limit detonations. For smooth tubes, the smallest tube diameter that will propagate a detonation is $=($ cell $\operatorname{size} / \pi)$. 
Larger diameters will propagate a detonation shock wave, but smaller diameters can not because the reflected shock waves will break up the primary wave front. For a stoichiometric hydrogen-air mixture, the minimum tube diameter is about $0.5 \mathrm{~cm}$ (Guirao, 1989). At the upper and lower explosion limits, the minimum tube diameter is about 0.3 meter. Propagation of a detonation in a channel requires that the channel width be at least as wide as the cell size. A similar phenomenon with flame quenching is seen for hydrogen flames. If two plates are closer than $0.5 \mathrm{~mm}$, a hydrogen flame cannot propagate because too much heat is lost to the walls for the flame to sustain itself (Drysdale, 1985).

If a hydrogen concentration range can be specified, then an automobile design can incorporate physical dimensions that would preclude propagation of detonations. An example might be the exhaust pipe diameter. For a hydrogen concentration of $18 \%$, if the tube diameter is less than $(0.3 \mathrm{~meter} / \pi)$, no detonation can propagate. Traditional exhaust pipes satisfy the criterion of $0.095 \mathrm{~m}$ if the concentration is as little as $18 \%$. As the concentration increases, the diameter reduces to $0.48 \mathrm{~cm}$ at $29.5 \%$ hydrogen.

\subsection{Bounding probabilities}

While much is understood about hydrogen combustion, an important aspect of safety that is not as well characterized is the likelihood of these combustion reactions when hydrogen is used as a vehicle fuel. Fire events are generally easier to quantify since they are mainly dependent on the system design characteristics and less dependent on weather influences.

Explosion events depend on the system design characteristics (such as storage pressure), the system's hydrogen inventory at the time of a system breach, and if the system can be isolated before a large amount of hydrogen can be released. Weather conditions at the time of a release (wind, air temperature, and other weather conditions are factors in mixing the hydrogen with air) must be accounted for. The release location is important to determine the obstacles that might promote turbulence in the combustion wave. The presence of weak or strong ignition sources in the vicinity and where they reside in the gas cloud is also important in determining if an explosion event can occur. The amount of hydrogen released is also important in defining cloud size and likelihood of a premixed system forming. Any detailed gas explosion analysis for the area under consideration must include hydrogen physical state upon release, weather, obstacles or confinement, gas concentration, and postulated ignition sources. It is unlikely that one automobile's inventory of hydrogen fuel (perhaps $5 \mathrm{~kg}$, Norbeck, 1996) would be adequate for a deflagration. Typically, a hydrocarbon vapor release to open air must be on the order of five hundred kilograms or more to allow a deflagration to occur (Vervalin, 1981), although some vapor cloud deflagrations have occurred with as little as 30 or $100 \mathrm{~kg}$ of hydrogen (CCPS, 1989). This is because the resulting gas cloud from a small mass catastrophic release of fuel from one vehicle into an open area will typically not create a volume large enough for a combustion wave to accelerate and build up damaging overpressure. A hydrogen combustion wave requires on the order of 35 feet $(10.7 \mathrm{~m})$ to reach significant overpressures (Lees, 1996). A chemical plant might release many tons 
of material that could vaporize, forming a vapor cloud hundreds of meters across. An automobile having a $5 \mathrm{~kg}$ hydrogen gas release, dispersed perfectly at $4 \%$ by volume in air is about $1,540 \mathrm{~m}^{3}$ of air (roughly $12 \mathrm{~m} \mathrm{x} 12 \mathrm{~m} \mathrm{x} 12 \mathrm{~m}$ ). That cloud is barely large enough to provide the run-up distance of approximately $10.5 \mathrm{~m}$ (Lees, 1996) for overpressure generation, and only if the ignition source was at the edge of the cloud rather than the center. An automobile having an $8.5 \mathrm{~kg}$ release (120 liters of hydrogen) would create a $4 \%$ hydrogen volume of about $2620 \mathrm{~m}^{3}$ (about $14 \mathrm{mx} 14 \mathrm{mx} 14 \mathrm{~m}$ ). The $4 \%$ hydrogen concentration will only remain for a short time, perhaps minutes (depending on weather conditions), until gas buoyancy and diffusion disperse the gas. As the gas disperses upward, a flammable mixture may continue to exist at altitude, and flames do rise more easily than they spread along the ground, making the rising release a challenging problem to model. A 5- or 8-kg fuel mass release into an enclosed location, such as a vehicle passenger compartment or a small garage, would present a deflagration hazard and a potential DDT safety issue. This is because the small volume means a rich mixture in the detonation range and confining walls that could reflect a combustion wave, building overpressure. Large releases from a refueling station [handling over $1,800 \mathrm{~kg} /$ day (Singh, 1995)] or a $\mathrm{LH}_{2}$ tank truck [on the order of 1,500 to $2,000 \mathrm{~kg}$ ] would also have explosion safety concerns.

Some typical probabilities for explosions following a gas release are given by Crossthwaite (1988) and are shown in Table 3-2. These values are given for multi-ton liquefied petroleum gas releases from a large plant, but are considered to be indicative of values for other energy gases and are therefore illustrative of generalized gas explosion modeling for large releases. These results would be considered for any large scale hydrogen release, such as from a refueling station. The immediate ignition probability within a few minutes of a large release of liquefied gas is 0.05 , resulting in a fireball or flash fire; and a 0.95 chance of leading to a more mixed system. Delayed ignition after many minutes or even hours resulting in a flash fire is a probability of 0.9 , and a vapor cloud deflagration explosion probability is 0.1 . This ratio was based on UK chemical industry experience with combustible gas releases. The UK flash fire to explosion ratio is typically about $4: 1$, but the analysts used 3:1 for windy unstable weather that promotes mixing, and 10:1 for slow wind, stable weather that tends to keep a gas cloud rich with modest mixing. For high momentum, highly turbulent large (i.e., 200 ton) releases, the analysts conservatively assumed a 1:1 ratio of flash fire to deflagration.

Siu (1998) also gave several probabilities for liquefied energy gas and other combustible material releases from road tankers that generally carry up to 8,000-gallon inventories. These values are presented in Tables 3-3 to 3-5, and are generally applicable to tank truck and station releases. Otherwise, probabilities will need to be evaluated on an individual basis for given station designs. 
Table 3-2. Explosion probability estimates given a flammable material release

\begin{tabular}{lccc}
\hline Breach size of release & $\begin{array}{l}\text { High } \\
\text { probability }\end{array}$ & $\begin{array}{l}\text { Medium } \\
\text { probability }\end{array}$ & $\begin{array}{l}\text { Low } \\
\text { probability }\end{array}$ \\
\hline $50 \mathrm{~mm}$ equivalent diameter & 0.8 & 0.6 & 0.4 \\
$25 \mathrm{~mm}$ equivalent diameter & 0.5 & 0.3 & 0.1 \\
$13 \mathrm{~mm}$ equivalent diameter & 0.1 & 0.05 & 0.01
\end{tabular}

Note: Analysts assigned the high, medium, and low probabilities. The assignment was based on ignition sources on the premises of, and in the vicinity of, a liquefied petroleum gas handling facility.

Table 3-3. Conditional probabilities of spills, given a transport truck accident.

\begin{tabular}{|c|c|c|c|}
\hline Fuel & $\underline{\text { Small Spill }}$ & $\underline{\text { Large Spill }}$ & Total \\
\hline Propane & 0.075 & 0.025 & 0.01 \\
\hline Gasoline & 0.09 & 0.07 & 0.16 \\
\hline Ethyl alcohol & 0.09 & 0.06 & 0.15 \\
\hline Hydrogen & 0.06 & 0.02 & 0.08 \\
\hline
\end{tabular}

Note: small spills involve $10 \%$ of tank inventory, large spills involve $100 \%$ of tank inventory.

Table 3-4. Conditional probabilities of immediate ignition, given a spill.

\begin{tabular}{|c|c|c|}
\hline Fuel & Small Spill & Large Spill \\
\hline Propane & 0.25 & 0.75 \\
\hline Gasoline & 0.15 & 0.50 \\
\hline Ethyl alcohol & 0.20 & 0.60 \\
\hline Hydrogen & 0.50 & 0.90 \\
\hline
\end{tabular}

Note: small spills involve $10 \%$ of tank inventory, large spills involve $100 \%$ of tank inventory. 
Table 3-5. Conditional probabilities of delayed ignition, given a spill.

\begin{tabular}{|c|c|c|}
\hline Fuel & Small Spill & Large Spill \\
\hline Propane & 0.68 & 0.23 \\
\hline Gasoline & 0.04 & 0.05 \\
\hline Ethyl alcohol & 0.04 & 0.04 \\
\hline Hydrogen & 0.45 & 0.09 \\
\hline
\end{tabular}

Note: small spills involve $10 \%$ of tank inventory, large spills involve $100 \%$ of tank inventory.

For propane and hydrogen, these probabilities are the total contribution from scenarios involving: a) ignition when the vapor cloud edge is over the population edge, and b) ignition when the vapor cloud center is over the population center. 


\section{Section 3 References}

AIChE, 1994. Guidelines for Evaluating the Characteristics of Vapor Cloud Explosions, Flash Fires, and BLEVEs, Center for Chemical Process Safety, American Institute of Chemical Engineers, 1994, chapter 7.

Bodurtha, 1980. F. T. Bodurtha, Industrial Explosion Prevention and Protection, McGraw-Hill Book Company, New York, 1980, ISBN 0-07-006359-1, chapter 4.

Brauer, 1994. R. L. Brauer, Safety and Health for Engineers, Van Nostrand Reinhold, New York, 1994, ISBN 0-442-01856-8, chapter 17.

Cassutt, 1959. L. H. Cassutt et al., "A Study of the Hazards in the Storage and Handling of Liquid Hydrogen," Advances in Cryogenic Engineering, $\underline{5}$, Proceedings of the 1959 Cryogenic Engineering Conference, Berkeley, CA, September 2-4, 1959, pages 55-61.

CCPS, 1989. Guidelines for Chemical Process Quantitative Risk Analysis, Center for Chemical Process Safety, American Institute of Chemical Engineers, New York, 1989, ISBN 0-8169-0402-2, section 2.2.

Ciccarelli, 1998. G. Ciccarelli et al., The Effect of Initial Temperature on Flame Acceleration and Deflagration-to-Detonation Transition Phenomenon, NUREG/CR-6509, US Nuclear Regulatory Commission, May 1998.

CFR, 1998. Title 40, Protection of Environment, Code of Federal Regulations, Part 68.25, Worst-case release scenario analysis, July 1, 1998.

Crossthwaite, 1988. P. J. Crossthwaite, R. D. Fitzpatrick, and N. W. Hurst, "Risk Assessment for the Siting of Developments Near Liquefied Petroleum Gas Installations," in Preventing Major Chemical and Related Process Accidents, Institution of Chemical Engineers Symposium Series No. 110, IChemE, Rugby, UK, ISBN 0-89116-065-5, 1988, pages 373-400.

Deshotels, 1995. R. L. Deshotels and R. D. Zimmerman, editors, Cost-Effective Risk Assessment for Process Design, McGraw-Hill, Inc., New York, 1995, ISBN 0-07006463-6, chapter 7.

DOT, 1996. 1996 North American Emergency Response Guidebook, a guidebook for first responders during the initial phase of a hazardous materials/dangerous goods incident, RSPA P 5800.7, US Department of Transportation, Washington DC, 1996.

Drysdale, 1985. D. Drysdale, An Introduction to Fire Dynamics, John Wiley \& Sons, Inc., Chichester, UK, 1985, chapter 6. 
Edeskuty, 1986. F. J. Edeskuty et al., Safety Aspects of Large-Scale Combustion of Hydrogen, LA-UR-86-669, Los Alamos National Laboratory, presented at the $6^{\text {th }}$ World Hydrogen Energy Conference, Vienna, Austria, July 20-24, 1986.

Edeskuty, 1988. F. J. Edeskuty and W. F. Stewart, Safety Aspects of Large-Scale Handling of Hydrogen, LA-UR-88-2045, Los Alamos National Laboratory, presented at the $7^{\text {th }}$ World Hydrogen Energy Conference, Moscow, USSR, September 25-30, 1988.

Edeskuty, 1996. F. J. Edeskuty and W. F. Stewart, Safety in the Handling of Cryogenic Fluids, Plenum Publishing Corporation, New York, 1996, chapter 7.

Eichert, 1986. H. Eichert and M. Fischer, "Combustion-related Safety Aspects of Hydrogen in Energy Applications," International Journal of Hydrogen Energy, 11, 1986, pages 117-124.

France, 1980. D. H. France, "Combustion Characteristics of Hydrogen," International Journal of Hydrogen Energy, $\underline{5}$, 1980, pages 369-374.

Friedman, 1998. R. Friedman, Principles of Fire Protection Chemistry and Physics, third edition, National Fire Protection Association, Quincy, MA, 1998, chapter 14.

Guirao, 1989. C. M. Guirao et al., A Summary of Hydrogen-Air Detonation Experiments, NUREG/CR-4961, US Nuclear Regulatory Commission, May 1989.

Lees, 1996. F. P. Lees, Loss Prevention in the Process Industries, hazard identification, assessment and control, second edition, Butterworth-Heineman, Oxford, UK, ISBN 0-7506-1547-8, 1996, volume 2, chapter 17.

NASA, 1968. Hydrogen Safety Manual, NASA TM-X-52454, N75-72909, National Aeronautics and Space Administration, 1968, section 8.

NFPA, 1991. Fire Protection Handbook, seventeenth edition, National Fire Protection Association, Quincy, MA, 1991, section 3, chapter 7.

Norbeck, 1996. J. M. Norbeck et al., editors, Hydrogen Fuel for Surface Transportation, Society of Automotive Engineers, Warrendale, Pennsylvania, 1996, ISBN 156091-684-2, chapter 2.

Pitblado, 1996. R. Pitblado and R. Turney, Risk Assessment in the Process Industries, second edition, Institution of Chemical Engineers, Rugby, UK, ISBN 0-85295323-2, 1996, chapter 3.

Popat, 1996. N. R. Popat et al., "Investigations to Improve and Assess the Accuracy of Computational Fluid Dynamic Based Explosion Models," Journal of Hazardous Materials, $\underline{45}$, 1996, pages 1-25. 
Porter, 1972. J. B. Porter, Analysis of Hydrogen Explosion Hazards, DP-1295, Savannah River Laboratory, July 1972.

Singh, 1995. S. P. N. Singh and A. A. Richmond, Hydrogen Fuel Dispensing Station for Transportation Vehicles, ORNL/TM-12982, CONF-9504160-5, Oak Ridge National Laboratory, 1995.

Siu, 1998. N. Siu et al., Interim Qualitative Risk Assessment for an LNG Refueling Station and Review of Relevant Safety Issues, INEEL/EXT-97-00827, revision 2, February 1998.

Strehlow, 1971. R. A. Strehlow, "Detonation Structure and Gross Properties," Combustion Science and Technology, 4 , 1971, pages 65-71.

Van den Berg, 1985. A. C. Van den Berg, "The Multi-Energy Method - A Framework for Vapor Cloud Explosion Blast Prediction," Journal of Hazardous Materials, 12 , 1985 , pages $1-10$.

Vervalin, 1981. C. H. Vervalin, editor, Fire Protection Manual for Hydrocarbon Processing Plants, volume 2, Gulf Publishing Company, Houston, Texas, ISBN 087201-288-3, pages 198-201.

Vervalin, 1985. C. H. Vervalin, editor, Fire Protection Manual for Hydrocarbon Processing Plants, volume 1, third edition, Gulf Publishing Company, Houston, Texas, ISBN 0-87201-333-2, chapter 2. 


\section{HYDROGEN HANDLING AND OPERATING EXPERIENCE}

This chapter presents information about large-scale uses of hydrogen. Hydrogen has been used as a lift gas for airships, as a feed for the chemical processing and refining industries, as a coolant gas, and as a propellant for spacecraft. Another section in this chapter discusses the use of hydrogen for automobile and other vehicle propulsion.

\subsection{Accidents}

This section gives information about hydrogen leaks and explosion events. As noted by Chamberlin (1998), there is an extremely negative public reaction to the use of hydrogen, particularly centering on memories of the airship Hindenburg event. Effort has been placed toward presenting the facts of that tragic event. As the next section shows, the Hindenburg was just one of a number of hydrogen airships that met with an accident involving the hydrogen lift gas. Of 129 hydrogen airships in the early 1900's, over onethird met with that type of accident (Lees, 1996).

4.1.1 Airships. One of the first uses of large quantities of hydrogen gas was in providing lift for dirigibles and zeppelins at the turn of the century. Hydrogen was chosen because it has $7 \%$ of the density of air and thus provides excellent lift to balloons and airships. Hydrogen also had the advantages of being much more plentiful and much less expensive than the next most likely candidate gas, helium. During World War I, the German Army and Navy used zeppelin rigid body airships for bombing cities in the United Kingdom. The German airshipmen maintained gas safety by keeping the hydrogen lift gas separated from air, precluding any combustion reactions. The zeppelins were rigid aluminum frame body structures, the interior was compartmented with gas cell membranes and the exterior was covered with fabric. The zeppelins flew very high, 3 to 4 miles in altitude, and although large, they had speeds on the order of $40 \mathrm{mph}$. They were hard to hit with anti-aircraft fire. A few German zeppelins that were hit by antiaircraft fire did burn, but several of the German airships hit by anti-aircraft shells during bombing raids over the United Kingdom did not burn or explode (e.g., the L-13, L-33). The battle damage allowed hydrogen gas to escape gas cells into the air, but the hydrogen did not ignite. The damaged airships lost lift because of the escaping gas; some crashed while others were barely able to make port. When the allied forces developed fast climbing, night fighting interceptor aircraft and began using incendiary (phosphorous coated) bullets in machine guns on those aircraft, the zeppelins began to suffer losses from hydrogen fires and explosions. The bullets breached the gas cells, and localized, sustained gunning with incendiary bullets would ignite the fabric and the escaping hydrogen gas (Cross, 1991).

The German airshipmen had strict safety rules that they could not vent off hydrogen for airship control during a storm, so they continually watched for weather changes. The airships withstood lightning strikes; some zeppelins, such as the L-11 airship, were lightning damaged to the point of fusing the aluminum girders in the bow. The storms 
also brought atmospheric pressure changes, and also the occasional sudden change in airship altitude caused by a storm could force the airship to vent some lift hydrogen so that the gas cells were not overpressurized. Vented hydrogen gas could be ignited by a nearby lightning bolt (Cross, 1991). Edeskuty and Stewart (1996), and Vervalin (1985) state that hydrogen in flare gas stacks can be ignited by atmospheric electrical discharges; a lightning strike within one or two kilometers is sufficient to ignite the flare gas. This phenomena is consistent with the low ignition energy of hydrogen in air.

The German airship base at Tondern suffered several hydrogen fires. Five zeppelins were lost because of accidents in handling hydrogen; these had nothing to do with enemy action. The L-18 zeppelin is an example of these accidents. The L-18 was a brand new airship being filled with hydrogen. A spark developed in a gas fill line, and the line exploded. This was a minor explosion, but it caused a nearby liquid fuel tank to explode. The fuel tank explosion spread flames to one of L-18's already-filled gas cells. The airship caught fire and was lost. Flames burned vigorously for over an hour (Cross, 1991).

These wartime experiences show that if the hydrogen is kept isolated or confined; that is, unmixed with air, then there is little danger of fire or explosion. The hydrogen must be kept above its upper flammability limit for airship usage. The wartime experiences showed that even energetic scale events (i.e., anti-aircraft shells striking or exploding within zeppelins, machine gun bullet impacts, lightning strikes) did not always cause gas fires or explosions. However, allowing the gas to leak out into air and then subsequently providing an ignitor allowed hydrogen fires and explosions.

After World War I ended, more countries had interest in airships. The United Kingdom (UK) held a national competition to fly across the Atlantic ocean in the 1920's; both airplanes and dirigibles attempted to cross. The United States offered to purchase an airship from the UK in 1921. The UK had built the R-38 airship from zeppelin plans but had elongated the airship to fit another gas cell in the center. The added gas cell improved the ceiling altitude obtainable to 25,000 feet. The R-38 was 85.5 feet in diameter and 699 feet long, carrying 2.7 million cubic feet of hydrogen for lift. It was the largest airship of that time. During the R-38's trial flights in July 1921, some of the structural girders buckled during a high speed run (presumably due to aerodynamic loading). The girders were repaired and trials continued. The R-38 was to become property of the United States in August 1921 after the final trial flight, and the US designated the airship Zeppelin Rigid-2, or ZR-2. Despite fog in England, the R-38 (ZR2) completed its final high speed trial run on August 24 and was flying over Hull, UK on its way to port for refueling before leaving for a transatlantic crossing to the US. The airship was under way at 2,500 feet altitude when it buckled in the middle. A split appeared in the bottom of the ship while the bow and stern rose. Witnesses saw what they thought was a slight fog around the airship as it lost altitude; that was presumably due to hydrogen gas venting. The airship began to fall toward the Humber river near 
Hull, dropping men and debris into the river as it fell. The two halves of the airship separated, and the forward half caught fire in the breakup. There could be many ignitors when a vessel suffers a structural failure - heat from overstressed metal, sparks generated by flying debris, severed electrical cables, etc. A hydrogen explosion followed. Several dozen townspeople outdoors in Hull were knocked to the ground. Glass windows in a two-mile radius were shattered. Readers should note that $0.15 \mathrm{psig}(1 \mathrm{kPa})$ is the threshold pressure for window glass breakage (AIChE, 1994) and 1 psig (6.9 $\mathrm{kPa})$ will knock people to the ground (Brauer, 1994). The event reminded the citizens of Hull of the zeppelin raids of World War I. If the hydrogen had detonated, the damage from a blast at less than 2,500 feet above a town would have been much worse than broken windows. When the R-38 broke up, the gasoline tanks for the propeller engines fell into the river and broke open. The burning forward section of the airship settled down to the river and ignited the gasoline for the propeller engines that had leaked out. The gasoline exploded and burned. That fire on the river ignited the drifting stern section. The burning stern section drifted further than the forward section; the stern came to rest on a sand bar where the river split. Forty-four of the forty-nine crew aboard were killed in that event (Toland, 1972).

The US successfully purchased an airship, the Roma, from Italy in 1920. This airship was the largest semi-rigid (a fore and aft metal frame, but the craft needed gas pressure to keep the body shape intact) construction airship ever built. It was over 400 feet long and contained 1.2 million cubic feet of hydrogen gas. By 1922 the airship had been delivered and reassembled in the US for service in the US Army. The original Ansaldo engines were replaced with more powerful Liberty engines; the Ansaldo engines were unreliable in the cold winter temperatures in the US. After high speed trials on February 21, 1922, outside Langley Field, Virginia, the Roma had trouble with trim. The bow sank, and the crew stopped the engines to right the craft. Investigation revealed that the high speed trials with more powerful engines caused the rigid bow to crumple under aerodynamic loads. The bow or nose failure resulted in gas bag punctures that allowed gas to leak; the airship lost lift. As it crashed, the Roma hit high voltage power lines on utility poles near Phoebus, Virginia. Witnesses reported a brilliant flash. That flash might have been the power lines parting, then witnesses heard a loud roar. The electrical arcing from parted wires were a strong ignitor, causing the hydrogen to explode (Schlager, 1994). The account does not specify if the explosion was a deflagration or a detonation. The hydrogen explosion caused the gasoline tanks (for the engines) to explode as well. Of the 45 people aboard, 11 survived the crash and explosions. There was an immediate public outcry against the use of hydrogen in airships in the US. The Army publicly argued that the cost of hydrogen to fill the Roma was $\$ 17,000$, but the cost of scarce helium would have been $\$ 120,000$. That is, a factor of seven increase in cost to use helium. The press responded by saying "if we can't afford helium, we can't afford dirigibles." Although helium has only 92 percent of the lifting capacity of hydrogen, no American airship ever flew again using hydrogen (Schlager, 1994). 
Undaunted by the R-38 failure in 1921, the United Kingdom built the R-100 and R-101 in 1929. They were both large airships (the R-101 was 131 feet in diameter and 777 feet in length). In 1930, the airship was assigned to take the Secretary of State for Air, Lord Thomson, to India. Lord Thomson had boasted to the press that the R-101 was "safe as a house, except for the millionth chance." The flight to India was meant to showcase the abilities of English airships. The airship launched in October 1930; it was heavily loaded. During the flight, the R-101 apparently lost hydrogen from one or more gas cells, the cause is not known. The airship lost lift due to the hydrogen leak and crashed outside of Beauvais, France (about forty miles northwest of Paris) during a rainstorm on October 5, 1930. By an unfortunate circumstance, calcium flares were in the control cab for use during flights across the English Channel. When the craft crashed, these flares were damaged. The exposed flares contacted water from rain and subsequently ignited. The burning flares ignited the hydrogen escaping from R-101's gas cells that ruptured on impact with the ground. The hydrogen exploded. The account does not specify if the explosion was a deflagration or a detonation; multiple flares burning are a strong ignitor so it is possible that a detonation occurred. One unharmed witness claimed to be only a few hundred yards away from the crash, therefore, a flash fire is the most likely combustion phenomenon. Only six people survived the crash; forty-eight people were killed. This event caused the United Kingdom to turn away from airships. The R-100 was scrapped and no further airship designs were pursued (Schlager, 1994).

The most well known accident event with a hydrogen dirigible was the Hindenburg disaster. Until that time, commercial German airships had a flawless safety record. The Graf Zeppelin airship alone had flown around the world, and had logged over a million passenger miles with no injuries to passengers. This value is perhaps small by today's standards, but in that era most dirigibles carried on the order of 50 passengers, so the value did represent many airship miles flown. The Hindenburg, airship LZ-129, was the largest airship ever built, at 135 feet in diameter, and 803 feet long. It held over 7 million cubic feet of hydrogen in sixteen gas cells (Toland, 1972). Sixteen compartments each contained a gas cell made from a cotton fabric, then a hydrogen impermeable layer of rubberized 'film', then another cotton fabric layer. Hydrogen gas pressure in each cell was on the order of 0.5 to 1 inch of water gauge (124.3 to $248.6 \mathrm{~Pa}$ above atmospheric pressure). The diffusion rate was about 1 liter of hydrogen per square meter of gas cell fabric per 24 hours. The airship outer skin was a linen fabric that was then coated with cellon 'dope' and aluminum powder mixture for weather protection. The outer fabric skin protected the gas cells and made the airship more aerodynamic. The dope (i.e., varnish) was used to waterproof and tauten the fabric cover. For ultra violet light protection, the inner surface of the fabric on the upper part of the airship was coated with red paint. The frame was built with aluminum-copper alloy girders. Girder rings were connected by straight section girders to form the characteristic ellipsoid shape. Wire cables were used to provide internal support for each ring. The gas cells were located between each girder ring. The frames of the Hindenburg were numbered in meters from the aft forward; frame 2 was near the tail and frame 247.1 was at the nose. 
The Hindenburg was originally designed for helium usage, but Germany was unable to purchase helium from the US. The US had passed a Helium Control Act in 1927. The helium supply was small and the US government did not believe that the new German government at that time had strictly peaceful intentions (Schlager, 1994). The Zeppelin Transport Company of Germany was forced to use hydrogen to fill the dirigible. The ship was fitted with precautions for hydrogen use. All crew ladders and catwalks were rubber encased to eliminate possible sparking, crew uniforms for use when inspecting the gas cells and ship's structure were made from asbestos without any metal (no metal fasteners, buttons, zippers, snaps, tabs, etc.) to eliminate static electricity generation and discharge. The crew shoes were either sneakers or felt boots to preclude static buildup. The axial passageway along the length of the airship and vertical shafts between gas cells were well ventilated, including use of natural draft air movement. Passengers were allowed to smoke tobacco, but only in designated smoking rooms that were under positive air pressure to ensure no hydrogen admission. Crew members helped passengers light their smoking products, and no passengers were allowed to possess matches or lighters during their voyage. Gas pressure sensors indicated pressure in each gas cell to the control car. The sensor elements were diaphragm pressure onto a spring loaded plunger within a wire coil (24 VDC, 100 ohms). A cell could lose only about 200 to 300 cubic meters of gas before the sensor readout would show a problem; this is only a very small portion of cell volume (a cell was about 12,500 cubic meters) (Knight, 1937).

The Hindenburg performed well, making thirty-four Atlantic crossings to Lakehurst, New Jersey and Rio de Janiero, Brazil in 1936 at an average crossing time of two and three days, respectively. The ship weathered storms well; passengers did not generally know how severe the weather was and they did not suffer from motion sickness because the airship had good stability in rough weather (Toland, 1972).

On May 6, 1937, the Hindenburg was due at Lakehurst, New Jersey at 6:00 am, having departed Frankfurt Germany two days earlier. Wind and rainy weather slowed the airship, it diverted around the worst of the storm. The Hindenburg passed New York City at $3 \mathrm{pm}$. The airship hovered along the coast to wait out a thunderstorm and allow for ground preparations. Because of the size of ground crew needed, only two times were scheduled to receive airships, 7 am and 7 pm (Toland, 1972). The airship approached the landing field at 6:00 pm, maneuvered to dock. Part of the docking procedure was to vent hydrogen and ballast as needed to steady the craft at the docking mast altitude and maintain gas cell pressure for differing barometric pressures at changing altitudes. The Hindenburg vented hydrogen from the five forward gas cells twice for 15 seconds while still decelerating from 73 to $27 \mathrm{mph}$, and decreasing from about 590 feet to 393 feet altitude. Hydrogen was vented once for 5 seconds while traveling at about $27 \mathrm{mph}$ on approach to the landing field. There was a 6 knot variable wind from the east. The airship then dropped a total of about 2,425 pounds of water ballast from frame 77 to trim the ship in preparation to dock (Knight, 1937). The airship passed through a small rain 
shower and a light rain was falling; the airship had successfully maneuvered around the heart of the thunderstorm. Spectators on the ground noted that the ship appeared to be slightly tail heavy as it approached. Then six members of the airship crew were sent to the bow to use their body weight as a means to help trim the craft even after the water ballast had been dropped. Crew movement for trim was an uncommon, but not unknown, practice for a large zeppelin. The airship captain noted some light rain and that there was a distant storm with lightning activity to the south and southwest. The sun had not set, so there was ample light for docking. As the ship approached the docking mast, it performed a sharp turn (varying testimony about how sharp the turn was) to face into the wind, which was shifting. Some ground crew noted that when Dr. Eckener piloted airships, he brought them in straight into the wind, slowed and "stopped on a dime". This captain performed a spectacular high speed, low altitude pass over the crowd of spectators and then a sharp turn to line up with the docking mast (Toland, 1972). The engines were run at full speed astern for about a minute to slow the airship. Then, with the Hindenburg about 200 feet above the ground, two 2-inch diameter manila rope lines from frame 244.5 (i.e., near the bow) were dropped to begin securing the airship. Dust came from the lines as they dropped to the ground, but the lines wetted in the light rain. The procedure was that a steel cable would moor the airship nose to the docking mast, and the manila ropes hold the airship into the wind and also prevent it from over-riding the mast. Only the port line had been attached to a ground winch used for drawing the airship down to ground level for disembarking passengers and cargo. The starboard line was being handled by ground crew at the time of the fire (Knight, 1937). The nose cable had been lowered about 50 feet but was not connected to the docking mast when the fire began. The airship never got closer than 700 feet (horizontal) to the docking mast. Ground crew saw the outer cover at the tail of the airship fluttering, and the skin of the airship seemed to be rippling. Since the propeller slipstream was far below that area, the ship had little headway, and the wind was light, the only reasonable explanation for the cover flutter is that hydrogen was leaking from a gas cell and causing the cover to move. At 6:25 pm, just after the port line had grown taut, a small tongue of flame emerged from where the skin had been fluttering. Ground crew then noted a red glow. Seconds later, burning hydrogen burst from the top of the airship. Photographs and witness testimony allowed investigators to conclude that the fire did start at the top of the craft, near gas cells 4 and 5 . The fire spread down the rear sides of the craft. The stern of the craft was engulfed in flame and began dropping. As the airship bow began pointing skyward, hydrogen flames shot up through the bow "like a blowtorch". The entire craft was afire and the frame collapsed. About 32 seconds had elapsed from the time the ground crew noted the red glow until the ship lay smoldering on the ground. Secondary fires, mainly of diesel fuel used for the propeller engines, burned for another three hours.

The combustion was a rapidly burning fire, not a deflagration explosion. Post-accident photographs show that the docking mast was intact, and the few injuries to the nearby ground crew and spectators show that it was not an overpressure event, only a fire. While the flames "shot up through the bow like a blowtorch", this is to be expected when a fire 
is introduced on a slope, since the flame radiant heating more easily preheats combustible materials (the hydrogen and the fabric) on a slope. Pre-heating combustible materials allows faster flame spread, and flame upward buoyancy would also allow easy propagation into unburned material. As the Hindenburg continued to settle by the stern, the slope continued increasing, allowing faster and faster flame spread. As shown in Chapter 2, hydrogen does not radiate as much heat as other materials, but the Hindenburg cover fabric and gas cell materials were also burning, which contributed to pre-heating the unreacted hydrogen. Fortunately, Captain Pruss allowed the airship to settle. The first instinct was to release ballast to trim the craft. Had he done so, the airship would have remained at too high an altitude and more lives would have been lost.

There was some speculation that the Hindenburg was sabotaged but there is no conclusive proof that any sabotage occurred. The German investigation of the accident concluded that, while definitive causes could not be found, the most probable cause was that a leak developed in gas cell 4 or 5 , possibly caused by a failed support wire inside the airship, possibly due to the sharp turn during landing. Sometimes support wires did fail, but they usually did not cause any leaks. The wreckage was too damaged to determine anything about the hull internal support wires. The leak caused a flammable hydrogen-air mixture to form in the upper part of the ship's stern. The gas mixture was ignited either by (a) a brush discharge after the ship was electrically grounded or (b) the airship frame grounded quickly through the port manila line but the wet outer fabric cover did not ground as quickly, allowing a voltage potential difference to develop and create a spark between the fabric and the aluminum alloy frame. The German investigators, including Dr. Eckener, favored scenario (b).

The American investigation included witness testimonies and photographic coverage of the accident, as well as investigation of the remains on the field. One witness from the port bow landing party of the ground crew discussed the flutter he saw in the fabric on the top port side of the airship. The German airship design and operations expert (and member of the German investigation team), Dr. Hugo Eckener, stated that a leak of hydrogen on the order of 40 to 50 cubic meters per second could cause the sort of fabric flutter described by the witness. He also stated that this leakage rate would not immediately be noticed on instruments in the control car. US investigators constructed an airship master diagram and marked eyewitness locations of fire origin. From that diagram the investigators concluded that the first open flame was on the top of the ship forward of the entering edge of the vertical fin over gas cells 4 and 5. The investigators believe that there was no detonation explosion after the fire began, just a very rapid burning of the hydrogen as it escaped from the gas cells. The investigators determined that the gas cell was not damaged by a propeller blade fragment; the propellers were recovered from the wreckage and shown to be intact when the craft impacted the ground. A plausible cause for the leakage was the fracture of a shear wire in the airship hull; a wire might have snapped during the last sharp turn to line the airship nose up with the mast and face into the wind. Possible gas combustion ignitors were discussed, including 
the pressure sensor, outgoing radio transmissions (transmissions ended 15 minutes before docking), mechanical friction heat from the airship structure, chemical reactions, electrical energy, and drive engine exhaust. Electrostatic energy seemed the most promising cause. Tests on the manila (hemp) rope showed that for conditions existing at the time of the accident, the airship could electrically discharge by $90 \%$ in a period of 0.6 to 170 seconds of the rope contacting the ground. A theory was advanced that a brush discharge from the airship fabric to the grounded part of the airship occurred because of the voltage potential gradients that existed at the field after thunderstorm passage. A brush discharge was proven to be able to ignite hydrogen in tests, and this discharge could not be seen in daylight. The American investigation concluded that a leak in the vicinity of gas cell 4 or 5 formed a combustible mixture, and it was probable that a brush discharge ignited the mixture.

The Hindenburg accident claimed the lives of 13 of the thirty-six passengers, 22 of the sixty-one crew members, and 1 ground crewman. While more people perished in the R38 and R-101 accidents, the public outcry was worse with the Hindenburg disaster. In the aftermath of the Hindenburg fire, all airships were grounded, and commercial airship travel ended later in May 1937 because of the perception on the part of companies and passengers that it was too dangerous (Schlager, 1994). Germany grounded the Graf Zeppelin, but also did construct the D-LZ130 airship in 1938. Again, the US did not supply helium for airship use, and the D-LZ130 used hydrogen. The D-LZ-130 was named the Graf Zeppelin, but it never flew passengers. After a few trial flights, the DLZ-130 was disassembled for parts in 1940 as Germany was involved in World War II. By 1939, the first airplane carried a paying passenger across the Atlantic, although transatlantic travel was not routine until after World War II. Despite the fact that nearly two-thirds of the people aboard survived the Hindenburg airship fire, the name Hindenburg came to mean any sudden, tragic technological disaster (Schlager, 1994).

There has been a valid concern that the Hindenburg fire taints the use of hydrogen as a fuel. That may be the public perception, but there are many easily distinguished differences between the Hindenburg and modern usage of hydrogen. The Hindenburg carried over 7 million cubic feet of hydrogen under less than 0.04 psig (an inch of water pressure). The gas was carried in fabric gas cells that were treated to reduce hydrogen diffusion rather than in a metal piping system, and by their nature, the gas cells were exposed to the elements at various altitudes. A modern hydrogen refueling station might store as much hydrogen gas as the Hindenburg; that is, a similar energy content as storing 10,000 gallons of gasoline in an underground storage tank. The hydrogen would be stored in an engineered material piping system, such as an alloy steel for gaseous hydrogen or a stainless steel for liquid hydrogen. The gas would be stored under pressure, perhaps 5,000 psig, and would be monitored for leakage, both by pressure sensors on the system and by gas detectors mounted at various positions in the refueling station. The storage would not be susceptible to a fire like the Hindenburg. The metal tank can not burn like the fabric gas cells did, and any overtemperature of the tank would 
activate relief valves that vent hydrogen up to disperse in the air. If a fire were to start at a dispensing line, then passive flame arrestor devices halt the propagation of flame back into the hose and down into the vehicle tank. Even without the flame arrestors, when the hydrogen concentration is too rich, the flame would extinguish. Hydrogen can be handled safely if physical properties are understood and precautions are made (SHA, 1998; Ringland, 1994).

The Hindenburg did not explode, even though the average person believes that it did. As stated earlier, this was a severe flash fire, not an explosion. If the Hindenburg had exploded, then the loss of life would have been much greater than actually occurred. Certainly the crew and passengers would have perished in the air. The ground crew would have suffered more than one fatality (wreckage did fall on one man) from the blast heat, overpressure, and debris missiles when 7 million cubic feet of hydrogen exploded. Spectators at the landing field would have had injuries and fatalities from the blast overpressure and heat exposure. While the Hindenburg was not the largest loss-of-life accident with an airship, it is the most memorable. Some reasons for this are the motion picture camera footage, the live radio broadcast, and the sensitivity of a foreign flag vessel having a catastrophic accident at a US port during a time of failing political relations with the country.

4.1.2 Chemical Industry. After the 1930's, airships no longer required hydrogen and the only large-scale demand for hydrogen was in the chemical industry. The use of hydrogen as a chemical reagent and as a rocket propellant has grown to over 8 million metric tons per year in the United States. Gaseous hydrogen is an important raw material for the chemical and petroleum industries. Chemical plants have used hydrogen as an element in various chemical manufacturing processes, to produce ammonia, methanol, cyclohexanol, and other chemicals (Shreve, 1977). The industry typically produces hydrogen by steam reforming methane into hydrogen and carbon dioxide as needed (Ramachandran, 1998). Hydrogenation is used for petroleum refining as well, to convert sulfur, nitrogen, oxygen, and other impurities into less troublesome chemical forms (Shreve, 1977). Chemical plants have had hydrogen releases and accidents. Most events are large releases, in multi-ton quantities, but some small releases are discussed here.

Ammonia production plants handle gaseous hydrogen as a feed to produce ammonia $\left(\mathrm{NH}_{3}\right)$. There have been hydrogen explosions at these facilities (Robinson, 1967). Nightingale (1989) describes a typical type of event. On August 3, 1987, a hydrogen explosion occurred where a welder was making maintenance repairs to defective piping. The welder was injured, but recovered from burns at a hospital. There was no damage to other personnel or the plant. Before the welding operation began, the location was checked for hydrogen. None was detected because of sampling right after a nitrogen purging sequence and a difficulty of air being inspired at the sample point. Hydrogen that was isolated from the work location was leaking past an isolation valve seat. The small amount of hydrogen mixed with air in the pipe; the welding current ignited it. 
A notable, tragic event at a styrene production plant occurred on April 20, 1984 (MacDiarmid, 1989). The styrene monomer plant used a hydro-dealkylation process on coke oven light oil to make benzene needed for the styrene production process. After a maintenance outage, the plant was starting up for a new production run. While increasing hydrogen system pressure past 600 psig, a loud "pop" was heard near the hydrogen compressor shed. About 10 to 15 seconds later, an explosion occurred. The explosion killed two employees that were heading toward the shed to investigate the noise, and seriously injured two more that were further away. The accident investigation revealed that the seal on the manhead tank entry for a knock-out drum of a hydrogen compressor had failed, leaking about $30 \mathrm{~kg}$ of hydrogen at high pressure. The hydrogen was semiconfined by the compressor shed roof, the deck of an adjacent structure, and by overhead piping. Ignition occurred under the compressor shed roof, but the exact ignitor was not given (perhaps static electricity from the gas release). A strong deflagration occurred 10 to 15 seconds after the release. The initial major fires burned out in 2 to 3 minutes. Unfortunately, a pipe flange was forced open by the blast and could not be isolated. The flange spilled benzene that burned for about 8 hours until it was consumed. Investigation of the compressed asbestos gasket piece recovered from the manhead tank entry showed it to be in nearly new condition, but the presence of a flaw in the gasket could not be ruled out.

These events show the spectrum of consequences from hydrogen accidents, even small releases. Hydrogen is by no means the only combustible material handled in chemical plants, and there is a great potential for combined reactions when so many other combustible materials are also in use. Despite these types of hydrogen accidents, hydrogen is still a fundamental part of many processes in the chemical industry. Through both regulation, such as enactment of the Process Safety Management Rule (29CFR1910.119) and the recent creation of the Chemical Safety Board for investigating chemical accidents, and the desire for cost-effective operation, chemical plants have undertaken efforts to make plants safer.

4.1.3 Power Plants. An unusual use of hydrogen gas, on a moderate volume scale, has been in the electrical generator cooling systems and other gas handling systems of modern power stations (Simion, 1993). Although hydrogen gas is flammable, it is used because of its properties of low viscosity and good heat transfer to remove heat from the generator rotor. The hydrogen is usually in the $75 \mathrm{psig}(620 \mathrm{kPa})$ pressure range, and Table 4-1 shows the hydrogen events that have occurred in systems of nuclear power plants through 1992. Presumably, since fossil fueled electrical generating plants use similar generator units, then they have also suffered from some of these types of events as well. 
Table 4-1. Hydrogen events in US nuclear power plants through 1992

\begin{tabular}{|c|c|c|c|c|c|}
\hline $\begin{array}{c}\text { Event } \\
\text { location }\end{array}$ & $\begin{array}{l}\text { Explosion } \\
\text { events }\end{array}$ & Fire events & $\begin{array}{c}\text { Leakage } \\
\text { (did not } \\
\text { combust) }\end{array}$ & $\begin{array}{l}\text { Other } \\
\text { events }\end{array}$ & Total events \\
\hline $\begin{array}{l}\text { Turbine } \\
\text { building, } \\
\text { generator } \\
\text { cooling } \\
\text { system }\end{array}$ & 2 & 7 & 7 & 0 & 16 \\
\hline $\begin{array}{l}\text { Hydrogen } \\
\text { storage } \\
\text { system for } \\
\text { turbine } \\
\text { coolant }\end{array}$ & 2 & 1 & 0 & 0 & 3 \\
\hline $\begin{array}{l}\text { Vapor } \\
\text { collection } \\
\text { tank cover } \\
\text { gas system }\end{array}$ & 0 & 0 & \begin{tabular}{l}
\multicolumn{1}{c}{11} \\
(10 were \\
hardware \\
faults, 1 was \\
a sampling \\
error)
\end{tabular} & 0 & 11 \\
\hline $\begin{array}{l}\text { Radioactive } \\
\text { waste gas } \\
\text { system; } \\
\text { radiolytic } \\
\text { hydrogen }\end{array}$ & 1 & 0 & 1 & 8 (a) & 10 \\
\hline $\begin{array}{l}\text { Lead-acid } \\
\text { Station } \\
\text { Batteries }\end{array}$ & 1 & 0 & 0 & 0 & 1 \\
\hline $\begin{array}{l}\text { Total } \\
\text { hydrogen } \\
\text { events }\end{array}$ & 6 & 8 & 19 & 8 & 41 \\
\hline
\end{tabular}


4.1.4 Aerospace Operations. An important report discussing incidents with hydrogen in aerospace operations was written by P. M. Ordin (1974). The report listed 96 incidents of releases of hydrogen, both gaseous and cryogenic. This study was performed on National Aeronautic and Space Administration (NASA) facilities. Twenty-six percent of the mishaps were caused by work area deficiencies, such as inadequate work conditions during installation or maintenance, or lack of training. Procedure deficiencies accounted for $25 \%$ of the mishaps. Design deficiencies accounted for $22 \%$ of the events. Planning deficiencies, such as test plans and hazard studies, resulted in $14 \%$ of the events. Component malfunctions (accountable to the component) resulted in $8 \%$ of the events. Material incompatibility and material failures accounted for 3\% of the events. These events were not catastrophic failures. Few events resulted in fires.

Bain (1976) discussed the technology used by NASA for liquid hydrogen handling, and one accident with a hydrogen trailer. The truck pulling a hydrogen trailer had an accident where a passenger car collided with the tractor-trailer. The trailer overturned. Hydrogen vented and was ignited by nearby burning diesel fuel from the tractor-trailer. Both drivers were injured, but the hydrogen burned off rapidly and did not contribute very much to the human injury or vehicle damage.

An important event in the history of the US space program is the space shuttle Challenger accident on January 28, 1986. Liquid hydrogen propellant played an important role in that event. The space shuttle is propelled by two types of rockets. The three main engines on the shuttle are fueled by 383,000 gallons of liquid hydrogen and 143,000 gallons of liquid oxygen. The total weight is about 790 tons. These fuels are stored in a large external tank (oxygen is in the tank's nose, hydrogen occupies the rest of the tank). There are also two solid rocket propellant boosters, one on either side of the large external tank. The solid boosters are constructed in cylindrical sections, with a joint between each section. When the Challenger was lifting off on mission 51-L, exhaust gases from the right solid rocket booster (SRB) began to leak from its aft field joint. The joint was not completely sealed, and the exhaust leakage was from the inboard circumference of the booster, facing the external tank. At 3.375 seconds after lift off, the hot exhaust gases were eroding the rubber o-rings, grease, and joint insulation, making black smoke puffs; the opening was enlarging. Investigators determined that a small flame was emanating from the aft field joint of the right solid rocket booster at 58.788 seconds into the flight. Chamber pressure of the left and right SRBs began to vary. The flame was deflected by the aerodynamic slipstream of the flying craft onto the external tank surface and also onto the lower strut that attached the SRB to the external tank. At 62 seconds into the flight, the control system began reacting to the forces created by the exhaust plume. At 64.66 seconds into the flight, investigators determined that the liquid hydrogen external tank had breached and was spilling hydrogen. At about 72 seconds, the lower strut linking the SRB to the external tank failed, allowing the SRB to rotate around its upper strut. Yaw and pitch between the two SRBs began to diverge, but control systems compensated to maintain flight path. At 73.124 seconds, the external tank structure began to fail; the entire aft dome of the tank dropped away. The liquid hydrogen contents began to release in that catastrophic failure, adding another $50 \%$ to the total thrust of the shuttle rockets. Over a span of milliseconds, the high amount of thrust 
from the released hydrogen pushed the hydrogen tank remains into the intertank structure. The rotating SRB also then impacted the intertank structure and the lower part of the liquid oxygen tank. The intertank structure and the liquid oxygen tank failed at 73.137 seconds. A massive hydrogen burn began with oxygen that was leaking from the breached liquid oxygen tank. While traveling at Mach 1.92 at 46,000 feet, the Challenger shuttle was engulfed in the hydrogen burn. The hydrogen burn destroyed the remains of the external hydrogen tank and caused the shuttle to experience even more severe aerodynamic loads than the increased thrust had caused. The SRBs parted from their struts and flew on, crisscrossing as they flew. Challenger's hypergolic propellants in its reaction control system began to burn. The shuttle broke up into sections under the severe aerodynamic loads that tore the wings and fuselage. Shuttle sections that were visible as the craft emerged from the hydrogen fireball were the tail with main engines still burning an oxygen rich mixture, one wing, and the forward fuselage (Rogers, 1986).

Bowen (1975) studied hydrogen accident events for the US military. An important issue raised from leakage events was flange, connection, and joint leaks. These connections in intermittent transfer lines repeatedly underwent thermal expansion/contraction cycling that led to leakage. Choosing materials with relatively low coefficients of thermal expansion (aluminum, copper, austenitic stainless steels, brass, monel or inconel) would alleviate some of the concern. Non-metals that were found to withstand liquid hydrogen are teflon, mylar films, and nylon. High pressure hydrogen gas has been noted to leak from seals that were tight against air or other testing gases.

Lippert (1976) conducted a set of tests with liquid hydrogen containers to determine the safety of these containers as fuel tanks for military aircraft. These tests involved firing armor piercing incendiary and fragment-simulator penetrator bullets into liquid hydrogen tanks. The penetrator bullets made holes; the pouring liquid hydrogen quickly evaporated when it contacted the ground. The incendiary projectiles caused deflagrations in the hydrogen. In another test, a liter of confined LH2 boiling under atmospheric pressure deflagrated but did not detonate with a simulated lightning strike of 4 megavolts and 50,000 amps.

4.1.5 DOE. The US Department of Energy funded a study of hydrogen events (Zalosh, 1978). Summarizing that study, more than 400 events were described in the US between 1965 and 1977. The events were described in case history style, with as much information as possible from source documents. Zalosh concluded that explosions were a serious problem, more than other hydrogen accidents, due to numbers of incidents, casualties, and property damage. Proper management of hydrogen safety was considered a necessity for its handling and use.

4.1.6 Other events. A few other hydrogen gas events were found in a brief literature review. The review was not performed to the depth of the compilations that were performed in the 1970's. The effort to identify cases such as these was modest due to funding and schedule constraints. The following paragraphs summarize a few more recent events noted in various publications. 
On October 31, 1980, a hydrogen explosion occurred in a support building at a test stand complex at the NASA Redstone complex in Alabama. The explosion destroyed two support buildings and severely damaged a large amount of equipment. Fortunately, no one was injured. Gaseous hydrogen leaked into one of the support buildings from a high pressure hydrogen gas system. The system piping was $88.9 \mathrm{~mm}$ (3.5 inch) outer diameter, carbon steel of $15.2 \mathrm{~mm}$ (0.6 inch) wall thickness meant to handle high pressures. The pipe had been attacked by galvanic corrosion on the outer wall for some time, thinning the wall to only $0.41 \mathrm{~mm}(0.016 \mathrm{inch})$ thickness. However, the pipe was not routinely under pressure. Just before the explosion, an isolation valve failed open, permitting hydrogen under a pressure of $29.6 \mathrm{MPa}$ (4300 psig) to enter the pipe and rupture the thinned wall. Gaseous hydrogen from two 19.8 cubic meter (700 cubic foot) tanks rapidly flowed out of the breach location. The gas leaked from one support building to the next. An electrical contact in a sump pump motor starter relay arced when the sump pump in the first building began an automatic start sequence. The electrical arc ignited the hydrogen in one building and this explosion apparently initiated an explosion in the other building. After that event, no mild steel was again used for high pressure hydrogen piping at that site (Youngblood, 1984).

In March 1983, some hydrogen gas cylinders were being offloaded from a truck in Stockholm, Sweden (Bjerketvedt, 1997). Hydrogen began to leak from one of the gas cylinders. The gas ignited; no details were given on the ignition mechanism. The blast wave from the explosion broke windows in a range of about 90 meters and sixteen people were injured. (Note: $1 \mathrm{kPa}$ is the threshold pressure for window glass breakage [AIChE, 1994]) This event showed that hydrogen is a reactive gas, and even open area explosions of hydrogen can create damage.

Ringland (1994) discussed some accidents with hydrogen. While the Air Products company had not lost any liquid hydrogen from its road tankers, the Linde division of Union Carbide did have one truck accident on August 25, 1987 near Columbus, Ohio. The truck overturned and lost vacuum insulation. The hydrogen boiled and vented, but there was no ignition. The possibility of ignition caused emergency response personnel to close the interstate highway and evacuate nearby homes and businesses.

Drogaris (1993) lists accident case histories from the 1980's for the European chemical industry. Nine of the 121 event descriptions discussed in the compilation included hydrogen as a combustible material. Three of those nine reports dealt with hydrogen as the primary (largest quantity or initial) substance involved in the accident. Briefly, these events were:

-1985, sulfuric acid corrosion generated hydrogen gas in a tank at a fertilizer plant; the gas was ignited by an oxy-acetylene weld cutter flame ( 2 fatalities).

-1988, an ammonia synthesis reactor had a hydrogen explosion during low pressure testing. The reactor had been leaking from some flanges and was undergoing a retest (1 fatality). 
•1989, a hydrogenated alcohol plant had a relief valve on a tank under inspection, hydrogen leaked from the valve under inspection. The hydrogen ignited in a jet fire (4 fatalities).

In October 1991, the Heraeus Quarzglas company, an optical fiber production firm in Hanau, Germany, suffered a hydrogen vapor cloud explosion. A $100 \mathrm{~m}^{3}$ storage tank containing $370 \mathrm{~kg}$ of hydrogen gas burst about 35 minutes after being refilled. The following vapor cloud explosion caused property damage and (fortunately) only a few personnel injuries. The tank had suffered a structural failure. Investigation revealed that the tank had been modified to position it vertically. Tank welds experienced increased tension because of the modification. Other reasons that reduced the tank lifetime, thus helped cause the tank to fail, were material fatigue, and hydrogen-induced aging (IWP, 1992).

Moskowitz (1995) described a hydrogen explosion event at a photovoltaic research facility at the University of Delaware. The event occurred on September 1, 1992. Hydrogen and other gases were set up to be piped into an enclosure that housed a chemical reactor. The chemical reactor used gases to deposit amorphous silicon thin films. The hydrogen gas cylinder was stored in a ventilated, fire sprinkler-protected gas cabinet. The gas supply piping to the reactor was constructed to allow a vacuum to be drawn on the line when needed. A technician erroneously opened a gas isolation valve in the wrong sequence, allowing $1,100 \mathrm{psig}(7.5 \mathrm{MPa})$ hydrogen to enter the vacuum line portion of the gas piping system. The vacuum line was not rated for that pressure, and a vacuum bellows burst. The failed bellows released about 0.5 cubic meter of hydrogen into the chemical reactor enclosure. The gas ignition cause was not clear. Investigators believed ignition was either due to mechanical pressure or a chemical reaction. The explosion caused plexiglas panels in the enclosure walls to blow out, as well as damage to ventilation exhaust ductwork and room ceiling tiles.

These events serve to illustrate the fact that hydrogen is highly flammable, and that when mixed with air it can produce intense fires. Some explosions have also occurred with this gas. Hydrogen might be present as a process gas, or it can be created during corrosion processes, chemical dissociation, or radiolytic decomposition. Many authors have discussed that hydrogen is a light, small molecule that quickly and easily disperses easily in air. Kletz (1988) pointed out that while most compressor houses at chemical plants are built without walls to provide better natural ventilation, a hydrogen compressor house was once built with metal sheet panel walls because hydrogen was not like other gases that can collect inside compressor houses. A few years later a hydrogen explosion destroyed that compressor house. While hydrogen can leak and does diffuse easily, it can still be delayed enough to build up concentrations above its lower flammable limit.

\subsection{Operating Experiences}

This section summarizes published experiences with hydrogen as a ground transportation fuel. Both gaseous and liquid hydrogen fuels have been considered, with internal 
combustion engines to a drive train and fuel cell-to-electric motor to a drive train applications.

Stewart (1984) discussed tests of a Buick Century automobile at Los Alamos National Laboratory. The car used an internal combustion engine to burn hydrogen-air mixtures. The car had been converted to store liquid hydrogen fuel on board. The fuel system did not suffer any leaks or releases of hydrogen other than routine boiloff from the fuel tanks. One safety-related issue that arose was with the vehicle liquid hydrogen dewar type 2 (VLHD-B). The liquid hydrogen fill, gaseous hydrogen return, and bypass valves tended to freeze in the open position during refueling. The reason for the freezeup was not known; tests with liquid nitrogen did not show any freezing tendencies.

Peschka (1987) discussed several events where liquid hydrogen fueled internal combustion engine cars were involved in accidents. The first was a jeep (mail carrier vehicle) experimental vehicle loaned to the University of California-Los Angeles (Finegold, 1976). The jeep was on a trailer to move the vehicle from the campus. The jeep's fuel tank was filled to capacity (50 gallons of LH2 at 28 psig) for use at its destination. The towing vehicle had a tire blowout at $55 \mathrm{mph}$, causing the trailer to sway and eventually overturn at a speed of about $20 \mathrm{mph}$. The trailer tongue broke, and the jeep came to rest upside down. The fuel system was not damaged in the rollover, and the jeep was unchained from the trailer and righted. The dewar top was cooled down by liquid hydrogen while the jeep was inverted, and researchers vented the tank for about 30-45 seconds to reduce the internal pressure from evaporated/boiled hydrogen. The tank supports were not damaged, nor was the fueling system. The uprighted jeep was driven back to the campus. The jeep tank had a pressure relief valve set for $32 \mathrm{psig}$, but the researchers chose to manually vent. Perhaps they chose to intervene because they could act before the tank pressure increased very much (i.e., vent less fuel mass in a manually controlled situation), and also relief valves have sometimes been known to not reseat properly after they lift. Peschka (1987) discussed two more events with a BMW 520 internal combustion engine vehicle. In the first event, the car was at a red stop light on a rainy night in Pasedena, California in 1982. A limousine struck the car from behind, pushing it about 7 meters out into the intersection. Some of the LH2 fuel system tubing was bent by deflections from forces in the collision, but no hydrogen leaked. In 1984, the same car was in Bonn, Germany, and had been placed on a trailer to be moved. While being towed, the trailer left the towing vehicle and turned on its side. The car needed a new windshield and some other parts, but the hydrogen tank and fueling system were intact. There were no leaks from the system.

Feucht (1988) discussed the test experience of ten hydrogen-fuelled vehicles used in Berlin. These were metal hydride storage, internal combustion engine vehicles. Five were passenger cars and five were vans. In the three-year test, there were no safetyrelevant malfunctions in the hydrogen systems. Buchner (1995) also discussed that fleet experience in Berlin. The vehicles accumulated over 700,000 km and typically had about 1500 fill cycles for the hydride tanks. The tanks needed about ten minutes to refill, at 3050 bar (atmospheres). The hydride storage tanks lost about 10\% capacity over the 1500 filling cycles. 
Knorr (1998) discussed the operating experiences of an internal combustion engine bus, fueled by hydrogen and gasoline. The hydrogen was stored as a liquid. The three vacuum insulated hydrogen fuel tanks were equipped with thermometers, pressure sensors, and capacitive level sensors. Electrical heaters were used to evaporate hydrogen when hydrogen gas depletion was needed. Above 3.8 bar (atmospheres) gaseous hydrogen was drawn off the tanks, and below 3 bar (atmospheres) liquid hydrogen was extracted from the tanks. The tanks were situated between axles of the buses, so they were well protected in case of collision or bus roll over. Protective panels were fitted beneath the tanks to prevent stone chipping or other road debris damage. The tanks were protected with an overflow valve and two pressure relief valves. If the valves opened, hydrogen would be vented through vent pipes up above the vehicle roof. Hydrogen sensors were installed near the tanks in the passenger compartment. If one of the sensors detected hydrogen, the tank system would shut off automatically and the bus skylights would also open. The bus driver also had an 'emergency' switch that would stop the hydrogen operation mode at any time. The bus has been operated for about a year, covered $10,000 \mathrm{~km}$ in city driving, and has not had any safety-relevant incidents or faults.

Chamberlin (1998) discussed experiences with fuel cell powered neighborhood and personal electric vehicles. These vehicles are not on par with traditional automobiles, they have lower top speeds (13-35 mph range) and shorter range (30 miles) than passenger cars. These three vehicles have been used for over a year on light maintenance and gardening activities in the City of Palm Desert, California. Proton exchange membrane fuel cells were used, with a 31.1 liter gaseous hydrogen storage tank on board. Personnel from the Schatz Energy Research Center at Humbolt State University performed the refueling, maintenance, and vehicle monitoring. When the temporary hydrogen refueling station was moved to city property, a refueling/maintenance technician was trained. There were no safety significant events reported in the year of operation.

Provenzano (1998) discussed the experiences of three Ford Ranger pickup trucks that had been converted to use compressed hydrogen gas at 3600 psi for fuel. The discussion of the fueling station mentioned electrical grounding as an essential safety precaution. Grounding the refueling station was accomplished using several ground rods, a massive copper cable, and brazed connections to assure that all equipment was at a common electrical potential. Vehicle grounding was accomplished by using a ground connector that must be used to open the fuel port door. The ground connector insertion and twisting causes a pin to retract. The pin retraction allow the fuel port door to open. Hydrogen leak detectors are installed on the three pickup trucks. No safety-related events were reported with the three trucks or with the prototype hydrogen-fuel cell bus (used for airport shuttle service at Los Angeles International Airport) that has been fueled at the same refueling station.

Summers (1998) discussed a hydrogen powered transit bus that used metal hydride storage. The bus was an electric bus that used an internal combustion engine to produce electricity for an electric drive train. Part of the battery energy storage was removed and 
metal hydride tanks were put in their place; this substitution doubled the bus driving range to $200 \mathrm{~km}$. The La-Ni-Al metal hydride tanks are said to be the largest in use, they weigh $1900 \mathrm{~kg}$, and store $15 \mathrm{~kg}$ of hydrogen. The bus operates in Richmond County and the city of Augusta, Georgia. The hydride adsorbs hydrogen at 7 atmospheres and $30^{\circ} \mathrm{C}$. The hydride desorbs hydrogen at $60^{\circ} \mathrm{C}$ and 13 atmospheres, using heat from the combustion exhaust gases. The bus had traveled approximately 1,000 testing miles in and around the City of Augusta at the time of Summer's report, and it had not suffered any safety-related problems. Insurance liability, licensing and refueling had all been addressed to allow operation of the bus. Regular passenger service was set to begin in the Spring of 1998.

Gilchrist (1998) and Spiegel (1999) discussed a PEM fuel cell powered electric motor bus used in Mexico City. Hydrogen gas was stored on board at 3600 psig. The fuel cell produced $205 \mathrm{~kW}$ (650 VDC at 315 Amperes) with an internal temperature of 85 to $90^{\circ} \mathrm{C}$. The fuel cell was stated to be $45 \%$ efficient, which is about double that of internal combustion engines. A $24 \mathrm{Vdc}$ startup battery (on-board) was used. The single bus in Mexico City showed no safety concerns over its two-day demonstration operating period in June 1997. One concern was that since Mexico City is at 7,400 feet of elevation above sea level, the $29 \%$ less dense air for the air flow cooling through the fuel cell effected bus operation. The less dense air led to about a $22 \%$ reduction in fuel cell power and to air compressor heatup. For a similar bus demonstration in sea-level Vancouver, British Columbia, air compressor temperatures generally stayed between 80 and $115^{\circ} \mathrm{C}$, while the Mexico City air compressor temperatures typically approached 120 to $130^{\circ} \mathrm{C}$. If a larger compressor were used, the overheating problem would be averted.

Szyszka (1998) discussed a fuel cell powered vehicle using hydrogen gas for fuel. The first was an electric fork lift, powered by a $10 \mathrm{~kW}$ electric fuel cell. The fuel cell was installed in the electric lift truck in place of the typical rechargeable battery pack. Power for all the lift truck auxiliaries was provided by the fuel cell, but an external battery was used for startup. The lift truck could operate for 8 hours on two $13-\mathrm{m}^{3}$ hydride tanks that stored hydrogen gas. The hydride fill operation took about 10 minutes and the heat generated in filling was dissipated by an external cooling water circuit. The hydride fill came from pressurized storage at between 10 and 30 bars. The lift truck performed safely in its trial run. Szyszka also mentioned that the hydrogen generating plant did suffer a local electrical cable fire in March 1991; the fire was extinguished by operators using hand-held fire extinguishers. That was the most significant safety incident at the plant in its ten year lifetime.

While many US and foreign operating experiences have been reported, most of the reports are initial experience (typically a year or two) for a handful of vehicles. The longest reported experience located in this review was the German testing of ten vehicles for three years. While the experiences are positive in that very few safety-related incidents have occurred, there is the concern that the future users of hydrogen fueled vehicles will not be as well trained and that typically the future vehicles may be handled with less care and poor attention to maintenance. More experience must be collected on 
US and other hydrogen vehicles to determine what use-related safety issues might present themselves to average users.

\subsection{Summary}

Hydrogen and other vehicle fuels pose a threat if they are released so that they may contact persons and if they mix with air to allow combustion. From operating experiences given above, usage of past safety assessments with natural gas vehicle fuel (Siu, 1998), and postulating fuel release events, a list of hazardous events is constructed. Events to consider for hydrogen fuel in vehicles are:

Vehicle fuel release due to system failure or system venting

Gas release under high pressure due to mechanical failure or overpressure venting (possibility of: pipe whip, gas jet cutting from pin hole leaks, air displacement in large release events, or pressure explosion)

Cryogen release due to mechanical failure or overpressure venting (possibility of: cryogenic burns, inhalation of cold vapors, hypothermia, air displacement in large release events, and eye damage. Metal embrittlement is also a concern.)

Vehicle fuel release due to external causes

Vehicle fire overheating fuel tank (vehicles can experience fires in hot parts, such as bearings, transmission, internal combustion engine, etc., see Tessmer, 1994)

Vehicle accident (collision with another vehicle, collision with stationary object, or vehicle rollover)

Road damage (debris from road surface is thrown up by wheels; debris impact damages the fuel tank, a fuel line, or perhaps the fuel cell)

Vehicle damage while parked (another vehicle collides with parked vehicle, exposure fire, etc.)

Vehicle fuel release during maintenance operations

Fuel mishandling or spill during fuel de-tanking for maintenance operations

Failure to correctly purge fuel tank after de-tanking for maintenance operations

Fuel tank overheating and venting during maintenance operations not involving fuel system

Fuel system collateral damage during maintenance operations not involving fuel system 
Vehicle fuel release during maintenance operations (continued)

Fuel system damage or loss of integrity during maintenance operations involving the fuel system

Refueling station release

Vehicle collides with fuel pump unit

Vehicle fueling error (improper hose connection, improper actions such as manual tank venting to speed up process, drive-away with refueling hose attached, etc.)

Tanker releases (tanker drive-away, tanker spills hose volume when uncoupling from station tank fill process, tanker involved in single- or multiple-car accident, tanker rollover, tanker hose failure during fill process, tanker hose improper connection during station tank fill process)

Mechanical failure of storage tank, tank penetration, valve, or hose

Fuel combustion

Fire after release from vehicle tank

Fire in fuel released during vehicle refueling operation

Fire in fuel released during tanker fill operation at refueling station

Deflagration after release from vehicle tank

Deflagration in fuel released during vehicle refueling

Detonation after release from vehicle tank

Detonation in fuel released during vehicle refueling

These events must be considered in a risk assessment, unless they are precluded by design. 


\section{Section 4 References}

AIChE, 1994. Guidelines for Evaluating the Characteristics of Vapor Cloud Explosions, Flash Fires, and BLEVEs, Center for Chemical Process Safety, American Institute of Chemical Engineers, 1994, appendix B.

Bain, 1976. A. L. Bain, "NASA Program Experience in Hydrogen Transportation and Handling," International Journal of Hydrogen Energy, 1, 1976, pages 173-188.

Bjerketvedt, 1997. D. Bjerketvedt, J. Roar Bakke, and K. van Wingerden, "Gas Explosion Handbook," Journal of Hazardous Materials, 52, 1997, pages 1-150, see page 13.

Bowen, 1975. T. L. Bowen, Investigation of Hazards Associated with Using Hydrogen as a Military Fuel, DTNSRDC 4541, accession number AD-A014 127, Naval Ship Research and Development Center, Annapolis, MD, August 1975.

Brauer, 1994. R. L. Brauer, Safety and Health for Engineers, Van Nostrand Reinhold, New York, 1994, ISBN 0-442-01856-8, chapter 17.

Buchner, 1995. R. Buchner, "Alternative Fuels in Ground Transportation," chapter 11, in H. W .Pohl, editor, Hydrogen and Other Alternative Fuels for Air and Ground Transportation, John Wiley Publishers, Chichester, UK, 1995.

Chamberlin, 1998. C. E. Chamberlin and P. Lehman, "The Palm Desert Renewable Transportation System," Proceedings of the 1998 U.S. DOE Hydrogen Program Review, Alexandria, Virginia, April 28-30, 1998, NREL/CP-570-25315, volume 2, 1998, pages 707-719.

Cross, 1991. W. Cross, Zeppelins of World War I, Barnes \& Noble Books, New York, ISBN 1-56619-390-7, 1991.

Drogaris, 1993. G. Drogaris, Major Accident Reporting System, lessons learned from accidents notified, Elsevier Science Publishers B. V., Amsterdam, 1993, ISBN 0444-81665-8.

Edeskuty and Stewart, 1996. F. J. Edeskuty and W. F. Stewart, Safety in the Handling of Cryogenic Fluids, Plenum Publishing Corporation, New York, ISBN 0-30645161-1, 1996, chapter 7.

Feucht, 1988. K. Feucht et al., "Hydrogen Drive for Road Vehicles - Results from the Fleet Test Run in Berlin," International Journal of Hydrogen Energy, 13, 1988, pages 243-250. 
Finegold, 1976. J. G. Finegold and . D. Van Vorst, "Crash Test of a Liquid Hydrogen Automobile," Conference Proceedings of the $1^{\text {st }}$ World Hydrogen Energy Conference, 1-3 March 1976, Miami Beach, Florida, published by the University of Miami, Coral Gables, Florida, 1976, paper 6C-97.

Gilchrist, 1998. T. Gilchrist, Fuel Cell Bus Demonstration in Mexico City, EPA-600/R98-039, PB98-142037, US Environmental Protection Agency, April 1998.

IWP, 1992. Interministerial Working Party of the Hessian Government, Germany, Report of the Interministerial Working Party regarding the Explosion Accident on the Site of the Heraeus Quarzglas GmbH in Hanu, October 5, 1991, published 1992.

Kletz, 1988. T. A. Kletz, Learning from Accidents in Industry, Butterworth \& Co, London, 1988, ISBN 0-408-02696-0, page 37.

Knight, 1937. R. W. Knight, A Comparative Digest of the German and American Reports of the Hindenburg Accident, US Department of Commerce, July 1937.

Knorr, 1998. H. Knorr, W. Held, W. Prumm, and H. Rudiger, "The MAN Hydrogen Propulsion System for City Buses," International Journal of Hydrogen Energy, 23, 1998, pages 201-208.

Lees, 1996. F. P. Lees, Loss Prevention in the Process Industries, hazard identification, assessment and control, second edition, Butterworth-Heineman, Oxford, UK, ISBN 0-7506-1547-8, 1996, volume 2, chapter 17.

Lippert, 1976. J. R. Lippert, "Vulnerability of Advanced Aircraft Fuel to Ballistic and Simulated Lightning Threats," International Journal of Hydrogen Energy, 1, 1976, pages 321-330.

MacDiarmid, 1989. J. A. MacDiarmid and G. J. T. North, "Lessons Learned from a Hydrogen Explosion in a Process Unit," Plant/Operations Progress, $\underline{8}$, April 1989, pages 96-99.

Moskowitz, 1995. P. Moskowitz et al., Lessons Learned from a Hydrogen Explosion at a Photovoltaic Research Facility, BNL-61322, CONF-941203-20, Brookhaven National Laboratory, 1995.

Nightingale, 1989. P. J. Nightingale, "Investigation into an Explosion that Occurred During a Welding Operation," Ammonia Plant Safety (and related facilities), 29, a technical manual published by AIChE, New York, 1989, pages 14-18.

Ordin, 1974. P. M. Ordin, Review of Hydrogen Accidents and Incidents in NASA Operations, NASA TM X-71565, NASA Lewis Research Center, accession number N74-28457, 1974. 
Peschka, 1987. W. Peschka, "The Status of Handling and Storage Technologies for Liquid Hydrogen in Motor Vehicles," International Journal of Hydrogen Energy, $\underline{12}$, 1987, pages 753-764.

Provenzano, 1998. J. Provenzano, P. B. Scott, and R. Zweig, "Demonstration of Fleet Trucks Fueled with PV Hydrogen," International Journal of Hydrogen Energy, $\underline{23}$, 1998, pages 289-293.

Ramachandran, 1998. R. Ramachandran and R. K. Menon, “An Overview of Industrial Uses of Hydrogen," International Journal of Hydrogen Energy, 23, 1998, pages 593-598.

Ringland, 1994. J. T. Ringland, Safety Issues for Hydrogen-Powered Vehicles, SAND94-8226, Sandia National Laboratories, March 1994.

Robinson, 1968. H. S. Robinson, "Fire and Explosion Risks in the Modern Ammonia Plant," Safety in Air and Ammonia Plants, 10, a Chemical Engineering Progress technical manual, AIChE, New York, 1968, pages 68-70.

Rogers, 1986. W. P. Rogers et al., Report of the Presidential Commission on the Space Shuttle Challenger Accident, Washington, DC, June 6, 1986.

Schlager, 1994. N. Schlager, editor, When Technology Fails, significant technological disasters, accidents, and failures of the twentieth century, Gale Research, Inc., Detroit, MI, ISBN 0-8103-8908-8, 1994.

SHA, 1998. Sourcebook for Hydrogen Applications, published by the Hydrogen Research Institute and the National Renewable Energy Laboratory, distributed by Tektrend International, Quebec, CA, 1998, chapter 2.

Shreve, 1977. R. N. Shreve and J. A. Brink, Jr., Chemical Process Industries, fourth edition, McGraw-Hill Book Company, New York ,1977, chapters 7, 37.

Simion, 1993. G. P. Simion et al., Risk Analysis of Highly Combustible Gas Storage, Supply, and Distribution Systems in PWR Plants, NUREG/CR-5759, US Nuclear Regulatory Commission, June 1993.

Siu, 1998. N. Siu et al., Interim Qualitative Risk Assessment for an LNG Refueling Station and Review of Relevant Safety Issues, INEEL/EXT-97-00827, revision 2, February 1998.

Spiegel, 1999. R. J. Spiegel, T. Gilchrist, and D. E. House, "Fuel cell bus operation at high altitude," Proceedings of the Institution of Mechanical Engineers, 213, Part A, 1999, pages 57-68. 
Stewart, 1984. W. F. Stewart, Operating Experience with a Liquid-Hydrogen Fueled Buick and Refueling Station, LA-UR-82-428, Los Alamos National Laboratory, June 1984.

Summers, 1998. W. A. Summers, "Savannah River Bus Project," Proceedings of the 1998 U.S. DOE Hydrogen Program Review, April 28-30, 1998, Alexandria, Virginia, NREL/CP-570-25315, CONF-980440-Vol2, 1998, pages 775-786.

Szyszka, 1998. A. Szyszka, "Ten Years of Solar Hydrogen Demonstration Project at Neunburg Vorm Wald, Germany,” International Journal of Hydrogen Energy, 23, 1998, pages 849-860.

Tessmer, 1994. J. Tessmer, An Analysis of Fires in Passenger Cars, Light Trucks, and Vans, DOT-HS-808 208, National Highway Traffic Safety Administration, Washington, DC, 1994.

Toland, 1972. J. Toland, The Great Dirigibles, their triumphs and disasters, Dover Publications, New York, ISBN 0-486-21397-8, 1972, chapter 17.

Vervalin, 1985. C. H. Vervalin, Fire Protection Manual for Hydrocarbon Processing Plants, third edition, volume 1, Gulf Publishing Company, Houston, Texas, ISBN 0-87201-333-2, 1985, page 189.

Youngblood, 1984. W. W. Youngblood, Safety Criteria for the Operation of Gaseous Hydrogen Pipelines, DOT/RSPA/DMT10-85/1, PB85-206159, US Department of Transportation, November 1984.

Zalosh, 1978. R. G. Zalosh and T. P. Short, Compilation and Analysis of Hydrogen Accident Reports, COO-4442-4, Factory Mutual Research Corporation, prepared for the US Department of Energy, October 1978. 


\section{Codes, Standards and Regulations for Safety}

This chapter summarizes existing codes, standards, and regulations about the safety aspects of hydrogen handling and usage as an energy carrier. Gaseous and cryogenic hydrogen are discussed. Bechtold (1997) stated that building codes for hydrogen storage and dispensing to vehicles do not exist, and nothing since that writing has been found to alter his finding. Bechtold stated that the most similar standard to compressed hydrogen storage and dispensing was National Fire Protection Association (NFPA) standard 52, and for cryogenic hydrogen storage and dispensing, NFPA standard 57. These two standards are for compressed and liquefied natural gas, respectively, and are discussed in this chapter.

\subsection{Hydrogen Handling.}

This section discusses rules in the Code of Federal Regulations (CFR), US Department of Energy (DOE) regulations, and consensus standards that may be adopted as law in individual States of the US. Initial direction was taken from Hord (1980) to identify various codes.

29 CFR. 29CFR1910.103 discusses gaseous and cryogenic hydrogen handling and storage. These rules apply to gaseous hydrogen containers of volume greater than or equal to 400 cubic feet $\left(11.3 \mathrm{~m}^{3}\right)$ of gas and cryogenic hydrogen containers of volume less than 150 liters (39.36 gallons). The gas storage tanks must be designed, constructed, and tested according to the American Society of Mechanical Engineers (ASME) Boiler and Pressure Vessel Code (B\&PV), Section VIII (Unfired pressure vessels) 1968 edition, or the tanks must comply with US Department of Transportation (DOT) specifications and regulations. The liquid tanks must comply with ASME B\&PV Section VIII, or applicable parts of American Petroleum Institute (API) Standard 620 (Recommended Rules for Design and Construction of Large, Welded, Low-Pressure Storage Tanks, June 1963). Gaseous hydrogen containers shall be equipped with safety relief devices as required by the ASME B\&PV Section VIII or by the US DOT specifications and regulations. Safety relief valves shall be arranged to discharge upward and unobstructed to the open air in such a manner that prevents impingement of escaping gas onto the container, adjacent structures, or personnel. The relief devices shall be designed so that moisture cannot collect and freeze in a manner that would interfere with proper operation of the device. Cryogenic relief valves will be designed in accordance with Compressed Gas Association pamphlet S-1, "Safety Relief Device Standards for Compressed Gas Storage Containers". A safety relief device shall be provided in piping wherever liquefied hydrogen could be trapped between piping closures. Piping for gaseous hydrogen shall conform to American National Standards Institute (ANSI) standard B31.1-1967, "Code for Pressure Piping". Piping gaskets and thread sealants shall be suitable for hydrogen service. Cryogenic piping has similar requirements, including thermal insulation that meets non-burning requirements of American Society for Testing and Materials (ASTM) standard D1692-68 and has a vapor-tight seal so that condensation of air and subsequent oxygen enrichment cannot occur in the insulation. 
The CFR also gives requirements on storage locations for gaseous and cryogenic hydrogen, and safe distances in feet to various types of building construction. These quantity-distance relationships are often stated for explosive or flammable materials. Generally, these distances are 25 to 50 feet for hydrogen systems over 15,000 cubic feet volume, but specifics vary with the situation and the regulation must be checked for individual applications. Buildings housing hydrogen storage must have ventilation, explosion venting, and heating provided by steam, hot water, or other indirect means. No ignition sources shall be present in the building from open flames, electrical or heating equipment. Gaseous and cryogenic hydrogen containers will be electrically bonded and grounded.

For mobile hydrogen supply units, a qualified person must be in attendance at all times while the unit is being unloaded. The mobile unit shall be grounded for static electricity, and roadways or other surfaces located below liquefied hydrogen piping from which liquefied air may drip shall be constructed of noncombustible materials. Drip pans may be installed below uninsulated piping and equipment to retain and vaporize condensed liquid air if the ground is surfaced with a combustible material (such as asphalt). For storage containers, any steel supports in excess of 18 inches in height shall be protected with a protective coating rated for 2 hours of fire resistance.

There are other regulations in this section of the CFR, but this discussion summarizes most of the occupational safety regulations that affect the safety design and operation of hydrogen systems.

29CFR1910.119, "process safety management of highly hazardous chemicals", states that a qualitative hazard analysis must be performed for chemical quantities over 10,000 pounds. The chemicals include flammable gases.

40CFR. In 40CFR68 ("Chemical Accident Prevention Provisions"), there is a discussion of safety issues with vapor cloud explosions. In section 40CFR86.25, titled "worst-case release scenario analysis", the direction for flammable substance releases is to assume that the substance vaporizes and results in a vapor cloud explosion. A yield factor of 10 percent of the available energy released in the explosion shall be used to determine the distance to the explosion endpoint (defined in the section as 1 psi overpressure) if the explosion model is based on trinitrotoluene (TNT) - equivalent methods. TNT equivalence is a standard modeling practice for explosions, even though all explosions are not high impulse pressure loading events like TNT explosions. The release point and the explosion endpoint distance are compared to the release point/site boundary distance to determine if the public could be exposed to the explosion endpoint's one-psi overpressure.

TNT-equivalent methods mean that the explosion blast effects, typically overpressure damage, are compared with TNT blast effects and an equivalency is determined. It is not simply an explosion energy released calculation, it is a comparison of resulting damage levels or blast effects (Noon, 1995). 
In 40CFR68.130, a threshold mass for accidental release prevention is given for hydrogen. As a flammable gas, hydrogen has a 10,000 pound $(4536 \mathrm{~kg})$ quantity threshold. The same mass applies to methane and propane. Designs must include provisions to prevent accidental release of hydrogen stored in this mass or greater. If a 120 liter liquid hydrogen tank in an automobile is assumed (estimate filling 100 liters/tank), and a fueling station that handles 300 vehicles/day (Daney, 1995), then about $2124 \mathrm{~kg}$ would be pumped per day. This result still leaves the question of how much reserve fuel is kept on site. Current practices at liquefied natural gas (LNG) stations are to accommodate an entire delivery tank truck inventory at one delivery. Assuming a similar situation for liquid hydrogen delivery, and realizing that there can be up to $20 \%$ loss from boiloff (Bain, 1976), a 13,000 gallon hydrogen tanker would deliver about 10,500 gallons (about $2814 \mathrm{~kg}$ ) of liquid hydrogen. Assuming a station would store two tankers' worth and thus have a tanker delivery every other day, then the on-site storage mass would be $5628 \mathrm{~kg}$, which is above 10,000 pounds. Therefore, large stations (e.g., truck stops, and high traffic stations at or above 300 vehicles/day) will require storing hydrogen above the threshold quantity, while small stations would only need to store subthreshold quantities. Large stations will have the added costs of provisions to prevent accidental releases.

49CFR. The Department of Transportation (DOT) has regulations on shipping and handling hydrogen gas and cryogenic hydrogen. Compressed hydrogen gas has an identification number UN 1049, and is hazard class labeled as a Flammable Gas. Gaseous hydrogen cannot be transported in passenger aircraft or railroad trains, but up to $150 \mathrm{~kg}$ can be carried in a cargo aircraft. Refrigerated liquid hydrogen (cryogenic liquid) has an identification number UN 1966, and it is also classed as a Flammable Gas. Liquid hydrogen cannot be transported on passenger or cargo aircraft, or on passenger rail trains. Hydrogen is not on the reportable quantity list of hazardous substances as given by the DOT (49CFR172.101). The DOT also sets rules for pressure relief, such as for cargo tanks. There must be two sets of pressure relief valves, called primary and secondary. Primary valves must allow total flow capacity at $120 \%$ of tank design pressure, while secondary valves must allow total flow capacity at $150 \%$ of tank design pressure. Backup pressure relief is also provided by primary and secondary frangible discs or pressure relief valves, which open at $110 \%$ and $130 \%$ of tank design pressure, respectively (49CFR173.318). For public highway transportation of hydrogen, the gas cylinders must be stored in DOT-4L containers, rest on flat surfaces and be well braced. Cryogenic hydrogen must be upright and have support that will withstand a 2 gravity horizontal acceleration. Total hydrogen boiloff from a vehicle must be less than or equal to 60 standard cubic feet of gas per hour, and the vehicle cannot enter a tunnel (49CFR177.840). Cryogenic liquids packaged in container over 450 liters (119 gallons) of water capacity shall avoid unnecessary delays during transport. If unforeseen conditions cause excessive pressure buildup, the driver shall manually vent the tank at a remote and safe location. The driver must check pressure at the beginning of the trip and every 5 hours over the duration of the trip (49CFR177.840). For cryogenic tanks, the tank pressure must be less than the marked rated holding time (MRHT) pressure and the one-way travel time (OWTT) must be greater than or equal to the elapsed time between the start and termination of travel (49CFR177.840). The holding time is defined as the 
elapsed time from loading a tank until the tank pressure reaches the level of lowest pressure relief setting. The rated holding time is the holding time when the ambient temperature is $85^{\circ} \mathrm{F}$. The MRHT cannot exceed the rated holding time.

Maintenance or repair of cargo vehicles placarded as carrying flammable gases cannot use heat, flame, or spark producing devices. Maintenance or repair cannot proceed inside a building unless several conditions are met. These conditions are: the vehicle containment system has been examined and found to not be leaking, personnel or means are available so that the vehicle can be immediately removed from the building in an emergency situation, and the vehicle is removed upon completion of the repair or maintenance work (49CFR177.854).

DOT 4L cylinders are used for flammable gas transport. A 4L cylinder is a fusion welded, stainless steel series 304 steel cylinder. The water capacity is not over 1000 pounds and service pressure is over 40 and not over 500 psig. For cryogenic hydrogen, the service temperature is $-423^{\circ} \mathrm{F}$ or below. Cryogenic units are insulated either with a fire resistant material or an evacuated jacket. The jacket must withstand a 30 psid collapsing pressure. The container must not have more than a 30 standard cubic foot/hour boiloff. Insulation must hold heat inleakage down at a temperature difference of $520 \mathrm{~F}$ so that the boiloff requirement is met (49CFR178.57).

The DOT also gives rules about tank construction for safety in collisions. Cargo tanks are designed in accordance with the ASME B\&PV code, and a safety factor of 4 is used in designing the tank supports. Increased static loads are assumed for protecting tank contents during collisions, doubling the loaded weight of the cargo tanks so that supports are built strong enough to withstand loading from a collision (49CFR178.337, .338). For cryogenic tanks, the inner tank must be designed so that the maximum stress from an impact collision is not more than $75 \%$ of the ultimate tensile strength. The pipes, hoses, penetrations, pumps or compressors, etc., must be protected from collision by either placing these items within the vehicle frame or by collision guards, etc., so that the colliding vehicle cannot strike this equipment or cause breakage. Discharge control devices have safety features to limit possible spills. Shut-off valves will be as close to the tank as possible. Discharge lines for flammables must have a remote control selfclosing shut-off valve. For tanks over 3,500 gallon water capacity, the shut-off valve must have a remote mechanical and thermal means of closure. If a fusible element is used as a thermal means of closure, it must actuate at no more than $250^{\circ} \mathrm{F}$. Hose couplings must be rated for $120 \%$ of design pressure to provide for leaktightness. Pipes, fittings, hoses and equipment besides relief valves or pump seals must be rated at 4 times the design pressure of the tank (49CFR178.338).

The DOT also specifies maintenance and inspection frequencies for cargo tanks. For MC 331 compressed gas cargo tanks, yearly external visual inspection, internal visual inspection every 5 years, and a pressure test every 5 years to 1.5 times the maximum allowable working pressure. For MC 338 insulated cargo tanks for cryogens, the same requirements apply except the pressure test is to only 1.25 times the maximum allowable 
working pressure. The tank shell and head wall thicknesses must be tested every two years (49CFR180.407).

A final section of potential importance is 49CFR193, Liquefied Natural Gas Facilities: Federal Safety Standards. This section covers siting, design, construction, site equipment, operations, maintenance, personnel qualification and training, fire protection, and site security for LNG centers. While this section applies only to gas distribution centers and not to consumer usage of natural gas, the direction can serve as valuable guidance for use of hydrogen as an energy carrier. The authors also noted another section in the code of federal regulations, 46CFR38, "liquefied flammable gases", but this section is a combination of Coast Guard and DOT, and applies only to transport by ship.

The DOT has also published a report on structural materials for use in hydrogen gas pipelines (Wyle, 1984). The report identifies several classes of metals that are acceptable for gaseous pipelines, namely: ferritic and martensitic alloy steels, austenitic stainless steels, age-hardened stainless steels, and special alloys. The report recognized that the lowest cost metals were low-to-medium strength ferritic and martensitic alloy steels. The report indicated that the CFR at the time, 49CFR192, did not adequately recognize the deleterious effects of high purity gaseous hydrogen on pipe steels and welds (embrittlement concerns). Hydrogen also has a higher leak rate than natural gas for the same given conditions. The experience with hydrogen pipelines at that time showed a safety attitude on the part of operators, since they were using lower strength pipes with thicker walls than needed, operated pipelines at low pressures, and radiographed all field welds. The pipelines at that time were in Texas, and were also protected in pipeline corridors that would prevent accidental damage from construction activity, digging, etc.

Consensus Standards. The National Fire Protection Association (NFPA) is a nongovernmental group that promulgates safe practices and standards on fire protection. Some states adopt all of the NFPA fire codes, many states adopt selected NFPA standards, and a few states only adopt a few of the most important NFPA guidance. Some of the better-known and important NFPA standards are the National Electrical Code (NFPA 70) and the Life Safety Code (NFPA 101). The state of Idaho has adopted the National Electrical Code (NFPA 70), the Uniform Building Code (UBC), and the Uniform Fire Code (UFC).

NFPA. For hydrogen, there are two important NFPA standards. One is NFPA 50A, the standard for gaseous hydrogen systems. The standard does not apply to single systems of hydrogen content less than 400 standard cubic feet $\left(11 \mathrm{~m}^{3}\right)$. Much of this standard is similar to the regulations in 29CFR1910.103 that were discussed earlier. One additional requirement that the NFPA standard states is that brazing materials for pipe joints shall have melting points above $1000^{\circ} \mathrm{F}\left(538^{\circ} \mathrm{C}\right)$.

The other important standard is NFPA $50 \mathrm{~B}$, the standard for liquefied hydrogen systems. This standard is very similar to 29CFR1910.103 portions that treat liquefied hydrogen. The NFPA appendix also states that materials suitable for use at liquid hydrogen temperatures include austenitic chromium-nickel alloys, certain copper alloys, and 
aluminum because they retain ductility (do not become brittle) at low temperatures. Liquid hydrogen storage should be located on ground higher than liquid oxygen storage. The standard states that protective means shall be taken (such as diking, diversion curbs, or grading) to prevent accumulation of liquids within 50 feet of the liquid hydrogen container.

NFPA 52 is the Compressed Natural Gas Vehicular Fuel Systems Code. This code has additional interest since it is also placed verbatim in the Uniform Fire Code (standard 521). NFPA 52 discusses the use and safety procedures for natural gas fuel systems that do not exceed $10 \mathrm{cfm}$ flow at 4,000 psig. NFPA 52 calls for containers and pressure relief valves that meet ASME and Compressed Gas Association standards. Gas compression, storage, and dispensing equipment must be located above ground, away from electric power lines, and a minimum of 10 feet from the nearest important building, line of adjoining property, ignition source, public street or sidewalk, and at least 50 feet from the nearest railroad rail. The minimum separation distance for containers and above ground tanks containing flammable or combustible material is 20 feet. For outdoor fueling, the fuel connection/transfer point must be at lest 10 feet from any important building, mobile home, public sidewalk, highway, street, and road, and it must be at least 3 feet from storage containers. To dispense natural gas to a vehicle, there are several rules: protect dispenser from vehicle collision damage, provide a plainly marked emergency shutdown system must, and keep delivery pressure below the maximum allowable vehicle fuel tank pressure. Fueling hoses must be a maximum length of 25 feet, have emergency shutoff valves and an emergency break-away device that can operate with a maximum force of 40 pounds in any horizontal direction.

NFPA 57 is the liquefied natural gas vehicular fuel systems standard, and would be applicable to liquid hydrogen fueled vehicles. NFPA 57 covers LNG engine fuel systems and dispensing facilities up to 70,000 gallons. Vehicle fuel containers are discussed. They must meet DOT rules or ASME B\&PV code rules. Pressure relief devices must meet Compressed Gas Association (CGA) standards. LNG fueling stations also have requirements. No sites near overhead power lines operating over 600 Volts. The LNG must have an impoundment area to contain the largest 10-minute duration release possible, allowing for snow or rain water accumulation, etc. Directions for LNG unloading from a transport tanker are obvious, such as no ignition sources in the area, tanker vehicle wheels rendered immobile (e.g., wheel chocks), and an unloading connection must be at least 1.5 feet from a storage container. A qualified person shall attend the transfer operation, prevent receiving tank overpressure, and for tanks over 2,000 gallons a backflow prevention device must be provided. To dispense LNG to a vehicle, there are several rules: protect dispenser from vehicle collision damage, provide a plainly marked emergency shutdown system, and keep delivery pressure below the maximum allowable vehicle fuel tank pressure. Fueling hoses must be 50 feet or less in length, and if over 3 inch diameter, they must have emergency shutoff valves and an emergency break-away device. The operator must secure the hose when not in use to protect it from damage. A fuel hose end connector and a vehicle mating receptacle shall be used for reliable, safe and secure transfer of fuel with minimal leakage. The connector must not allow release when the line is open, or it must have self-closing ends that will 
close upon disconnection. Another important issue is the 6-month inspection frequency for safety and fire protection equipment.

Standards NFPA 88A (parking structures) and NFPA 88B (repair garages) do not mention hydrogen alternative fueled vehicles, but they do mention natural gas powered vehicles. The parking garage standard calls for meeting NFPA 30A (Automotive and Marine Service Station Code) if flammable liquids are stored, handled, or dispensed. Heating equipment shall meet NFPA standards, and no improvised heaters (salamanders, space heaters, improvised furnaces) are permitted. The structures must be ventilated. If natural gas is used, then the parking structure must comply with NFPA 52 and NFPA 57.

NFPA 88B states that if natural gas vehicles are repaired or stored in the repair garage, then no open flame heaters or heating equipment with exposed surfaces having a temperature in excess of $750^{\circ} \mathrm{F}\left(399^{\circ} \mathrm{C}\right)$ are permitted. Below grade areas in the repair garage will be continuously ventilated at a rate of not less than $1 \mathrm{cfm}$ per square foot (or 1 $\mathrm{m}^{3} / \mathrm{min}$ per $\mathrm{m}^{2}$ ) of floor area. Inspection and repair pits must have either natural circulation air or they must have a ventilating system capable of a complete pit air change every 5 minutes. The air intake from the pit shall be near the floor level. Repairs on compressed and liquefied gas fuel tanks shall be performed only by a qualified manufacturer, and in accordance with the applicable US DOT regulations (49CFR177).

NFPA 30A (Automotive and Marine Service Station Code, 1996) contains many rules for design of refueling stations that handle gasoline, diesel fuel, and even natural gas. For example, tanks storing gasoline shall have vent pipes that discharge upward to disperse vapors. Above ground tanks shall be resistant to damage from the impact of a motor vehicle or will be protected by collision barriers. Delivery vehicles shall be separated from any above ground tank by at least $7.6 \mathrm{~m}$ (25 feet). There is no minimum separation distance specified for gravity filled tanks. Dispensing devices shall be mounted on a concrete island or otherwise protected against collision damage. Hose assemblies shall not exceed $5.5 \mathrm{~m}$ (18 feet). Emergency breakaway devices will be installed on hoses so that liquid is retained on both sides of the hose that dispenses Class I liquids (such as gasoline) in the event of a vehicle drive-away. Dispensers for liquefied petroleum gas, CNG, or LNG shall be at least $6 \mathrm{~m}$ (20 feet) away from Class I liquid (e.g., gasoline) dispensing devices. Any spilled liquid will be precluded from flowing into the interior of buildings by grading driveways, raised door sills, or other means. Smoking materials, including matches and lighters, shall not be used within $6 \mathrm{~m} \mathrm{(20} \mathrm{feet)} \mathrm{of} \mathrm{areas} \mathrm{used} \mathrm{for}$ fueling, servicing of fuel systems, or receiving/dispensing of Class I liquids (such as gasoline). It is expected that hydrogen gas could have requirements similar to those for compressed natural gas (Berthold, 1997).

There are other NFPA standards that are applicable to refueling stations, but would apply to all stations regardless of the type of fuel. These are the NFPA 70 (National Electrical Code), NFPA 77 (Static Electricity), NFPA 78 (Lightning Protection), and NFPA 220 (Standard on Types of Building Construction). 
NASA. The National Aeronautics and Space Administration (NASA) has composed a safety standard for hydrogen (OSMA, 1997). This large document is quite thorough in its treatment of hydrogen in gas, liquid, and slush forms. This safety standard was used extensively in the Sourcebook for Hydrogen Applications (SHA, 1998). The NASA document covers safety guidelines, hydrogen properties, materials compatibility with hydrogen, hydrogen handling, hydrogen storage, fire detection, operating procedures, hydrogen transportation, and emergency procedures. While this standard is not a legal requirement, it does represent best practice information from an agency that has handled very large quantities of liquid and gaseous hydrogen for several decades. For example, the space shuttle, which had its first launch in 1981, uses over 300,000 pounds of liquid hydrogen per launch.

CGA. The Compressed Gas Association (CGA) has several standards pertaining to hydrogen gas. The CGA hydrogen standard (CGA, 1991) discusses hydrogen in portable gas cylinders, including topics of regulations for hydrogen gas cylinders, handling and storage. An important change from other gas cylinder handling is that a hydrogen gas cylinder should never be 'cracked' open. This practice of a quick, partial opening and then reclosing of the gas valve is typically performed so that a small amount of gas sweeps any dirt or debris from the gas valve outlet prior to connecting the pressure regulator. A puff of hydrogen could self-ignite, while other gases typically will not. If a gas cylinder is found to be leaking, the first step should be to close the valve. If that act stops the leak, then the cylinder should be carried outside and tagged as unserviceable. If valve closure does not stop the leak, then the cylinder should be carefully moved outside. Warnings should be posted about hydrogen flammable gas, and keep people away from the cylinder since hydrogen is very easily ignited and burns with a nearly invisible flame.

In its standard for hydrogen piping (CGA, 1992), the ASME piping code B31.3 was identified as the design guidance for piping in hydrogen service. Austenitic stainless steel is recommended for cryogenic or gas service at low temperatures, and carbon steel was discussed for warm gas (i.e., room temperature and higher) service. Piping site location was specified to agree with NFPA $50 \mathrm{~A}$ or $50 \mathrm{~B}$ for protection against fire exposure. Pressure relief devices should comply with DOT regulations or ASME code requirements. Hydrogen gas detectors may be installed to sense gas leakage, with setting to alarm at $1 \%$ hydrogen (which is one-fourth of the lower flammable limit) and shut down at $2 \%$ hydrogen. Detectors are typically not required for outdoor systems. Means of performing system cleaning (inside pipes, etc.) were discussed. The standard also called out 29CFR1910.103 for requirements regarding installation of hydrogen storage systems.

Another CGA standard discusses proper hydrogen venting techniques (CGA, 1996). Vent sizing to obtain proper gas velocity and pressure drop without impeding flow from the pressure relief devices was discussed. The ASME B31.3 code, CGA guidance, American Petroleum Institute guidance, and NFPA guidance were called out. A stack length to diameter ratio of 60:1 or greater could allow a deflagration in a vent line, and over 100:1 a hydrogen-air detonation is possible. Piping suitable for hydrogen gas, such as carbon steel, was cited for stack construction, while austenitic stainless steel was given 
as the preferred choice for venting cryogenic hydrogen gas. An important operational safety caution was to never vent liquid hydrogen without first vaporizing the product. The liquid changing to vapor in the vent line could overpressurize the line. Maintenance personnel should always assume that a hydrogen-rich gas is present in the stack and purge the vent system before performing any operations.

DOE. The Department of Energy does not have any specific orders, directives, or standards for hydrogen gas handling. The DOE complies with the Code of Federal Regulations, so it must meet 29CFR requirements as discussed above. In general, the DOE also complies with industry standards and best safety practices for a given activity or operation, so the NFPA and other standards would be important to designers, operators, maintainers, users, and other personnel.

\subsection{Hydrogen fueling}

The building codes and other safety-related documentation discuss refueling service station design and operation. As noted above, the State of Idaho has adopted the UBC and UFC.

UBC. The Uniform Building Code (UBC, 1997) section 311 classifies repair garages with no open flames or welding, motor vehicle fuel dispensing stations, and enclosed parking garages as Group S, Division 3 occupancies. Open parking garages are classified as Group S, Division 4 occupancies. Building heights are set, and floor surfaces must be constructed of noncombustible, nonabsorbent materials or surfaced with asphaltic paving materials. Floors shall drain to an approved oil separator or trap, discharging to sewers. The fuel-dispensing stations and any canopies or covers over the dispensers, must be constructed of one-hour fire-resistive construction or noncombustible, fire-retardanttreated wood. Canopy heights must be at least 13 feet 6 inches to the lowest projected element in the vehicle drive-through area. Devices generating a glow, spark, or flame capable of igniting flammable vapors shall be installed so that the sources are at least 18 inches from the floor of any room in which Class I flammable liquids or gases are used or stored. Storage and use of combustible liquids shall be in accordance with the Uniform Fire Code.

UFC. The Uniform Fire Code (UFC) Section 2903 (UFC, 1997) discusses repair garages, specifically mentioning hydrogen and LNG fueled vehicles. The UFC requires flammable gas detection systems for repair garages that service hydrogen and LNG fueled vehicles. The detector shall actuate when the level of flammable gas exceeds 25 percent of the lower explosive limit. The detector shall initiate distinct audible and visual alarm signals, deactivate all heating systems in the garage, and activate the mechanical ventilation system. If the detector fails during routine monitoring operations, it shall failsafe by deactivating the heating system and activating the ventilation system. Vehicle fuel shutoff valves shall be closed prior to repairing any portion of the vehicle fueling system. If the vehicle suffered damage to the fuel system, the system shall be inspected and evaluated for integrity prior to entry into the repair garage. The inspection shall include use of a gas detector on the entire fuel delivery system. 
UFC section 5204 (UFC, 1997) discusses compressed natural gas fuel-dispensing stations for motor vehicles. The maximum capacity for a compressed natural gas station is 183,000 cubic feet of gas storage. Qualified attendants trained in proper handling of CNG will conduct fueling operations. Dispensers must not be beneath power lines, and must be more than ten feet from the nearest building or property line that could be built upon, any public street, sidewalk, or ignition source. A dispenser shall have an emergency shutoff switch within 75 feet but not less than 25 feet from the dispenser. The gas storage cylinders will be grounded and bonded in accordance with the electrical code.

UFC section 7403 (UFC, 1997) discusses compressed gas handling and cites the CGA standard on safe handling of compressed gases to transfer gases between containers, cylinders and tanks. Section 8004 discusses dispensing flammable gas and other hazardous material fuels, and cites a distance of 10 feet separation between storage location and public ways (streets, sidewalks, etc.) for gaseous systems between 4,226 and 21,125 cubic feet volume. Other quantity-distance relationships are given for different

system volumes. Spill control features will be built into an outdoor liquid dispensing facility, including a liquid-tight sloped floor or recessed floor to drain spilled liquid, liquid-tight raised sills or dikes to buildings, and sumps or liquid collection systems. These systems must be constructed of noncombustible material and be chemically compatible with the fuel material. A continuous gas detection system shall be provided to detect the presence of a chemically toxic gas at or below the permissible exposure or ceiling limit (hydrogen has not threshold limit value; only flammable gas detection is suggested in Section 2903). The detection system must initiate a local visual and audible alarm, and signal a constantly attended control station. The alarm must signal to both outdoor and any indoor locations at the facility.

\subsection{Summary}

These codes, standards and regulations place requirements and some restrictions on the design and construction of refueling stations, as well as on the vehicles themselves. Some of the rules conflict with each other, and the safety approach would be to understand why the rule exists and choose the safest means of eliminating the hazard from the design. However, sometimes the most restrictive of the rules is chosen to easily demonstrate that the design is complying with the rules. An example is the length of a refueling hose. Various standards direct 50 to 18 feet maximum length. Unless there is a compelling reason to choose a longer hose, the 18 feet would be used. Considering the breadth of the standards and the requirements that also apply to gasoline stations, there are no high cost added requirements for alternate fuel stations, other than potentially needing a combustible gas monitoring system. 


\section{Section 5 References}

Bain, 1976. A. L. Bain, "NASA Space Program Experience in Hydrogen Transportation and Handling," International Journal of Hydrogen Energy, 1, 1976, pages 173188.

Bechtold, 1997. R. L. Bechtold, Alternative Fuels Guidebook, properties, storage, dispensing, and vehicle facility modifications, Society of Automotive Engineers, Inc., Warrendale, PA, ISBN 0-7680-0052-1, 1997, page 157.

CGA, 1991. Compressed Gas Association, Inc., Hydrogen, fourth edition, CGA G-5, CGA, Arlington, VA, 1991.

CGA, 1992. Compressed Gas Association, Inc., Standard for Hydrogen Piping Systems at Consumer Locations, first edition, CGA G-5.4, CGA, Arlington, VA, 1992.

CGA, 1996. Compressed Gas Association, Inc., Hydrogen Vent Systems, first edition, CGA G-5.5, CGA, Arlington, VA, 1996.

Daney, 1995. D. E. Daney et al., "Hydrogen Vehicle Fueling Station," LA-UR-95-2464, Los Alamos National Laboratory, presented at the 1995 Cryogenic Engineering Conference, Columbus, Ohio, July 17-21, 1995.

Hord, 1980. J. Hord, "Hydrogen Safety: An Annotated Bibliography of Regulations, Standards and Guidelines," International Journal of Hydrogen Energy, 5, 1980, pages 579-584.

Noon, 1995. R. K. Noon, Engineering Analysis of Fires and Explosions, CRC Press, Boca Raton, Florida, 1995, chapter 6.

OSMA, 1997. Office of Safety and Mission Assurance, Safety Standard for Hydrogen and Hydrogen Systems: Guidelines for Hydrogen System Design, Materials Selection, Operations, Storage, and Transportation, NASA TM-112540, NSS 1740.16, National Aeronautics and Space Administration, Washington, DC, October 29, 1997.

SHA, 1998. Sourcebook for Hydrogen Applications, published by the Hydrogen Research Institute and the National Renewable Energy Laboratory, distributed by Tektrend International, Quebec, CA, 1998.

UBC, 1997. Uniform Building Code, International Conference of Building Officials, Whittier, CA, April 1997.

UFC, 1997. Uniform Fire Code, International Fire Code Institute, Whittier, CA, March 1997. 
Wyle, 1984. Wyle Laboratories, Safety Criteria for the Operation of Gaseous Hydrogen Pipelines, DOT/RSPA/DMT-10-85-1, PB85-206159, prepared for the US Department of Transportation, November 1984. 


\section{CONCLUSIONS}

Several facts are evident from this report. Hydrogen has been in widespread, large scale use for perhaps 100 years around the world, first as a lift gas in dirigibles and then as a fuel for spacecraft rocket engines. While there have been some very tragic and notorious accidents with hydrogen use, the dangers and phenomena are now generally understood and well recognized.

An example of this growth in understanding is that the airship Hindenburg accident report in 1937 cited a low value of the upper flammability limit of hydrogen in air, between 62 and $66 \%$, which is now understood to be $74 \%$. The Hindenburg event has become synonymous with a technological disaster, remembered by many as a terrible explosion. The facts show that the Hindenburg accident was one event in a long history of hydrogen airship accidents.

Nevertheless, the use of hydrogen as a chemical reagent and as a rocket propellant has grown to over 8 million metric tons per year. The public attitude about hydrogen must be changed by continued safe use to allow acceptance of hydrogen as a vehicle fuel. Changing attitudes will be difficult for many reasons; including the technical challenges of understanding unconfined combustion and explosion phenomena.

With proper precautions, hydrogen can be handled safely. No safety issues are foreseen that would warrant cessation of hydrogen use as a vehicle fuel. Important examples of handling safety are that NASA has stored and handled very large quantities of hydrogen safely in ground systems at spaceports for decades, and the small amount of hydrogen car operating experience to date has also been safe. Knowledge about hydrogen physical properties has increased, including accident modeling and prediction. Modeling of gas releases and gas mixing in enclosures is growing more and more detailed with the use of computational fluid dynamic computer codes. These models would be important to predict gas behavior in natural- and forced-ventilation enclosures, such as underground parking garages, tunnels, residential garages, and passenger compartments of automobiles. Dealing with outdoor hydrogen releases is still a challenge for risk analysis, since it combines probabilistic techniques of predicting release location, breach size, and presence of ignition sources with the deterministic weather conditions occurring at the moment of release. The weather (wind speed, insolation, air temperature, etc.) will determine the hydrogen concentration in air. This probabilistic/deterministic complication is the main reason why some analyses assume the worst case detonation of gas in air to give an upper bound of consequences from a gas release event even though the likelihood of an open-air detonation event is quite remote. Detonation requires a strong ignition source (i.e., over ten thousand Joules of energy rather than a millijoule spark), a rich gas mixture in air, and generally some form of shock wave reflection that means confining the gas-air mixture in some way. A hydrogen-air deflagration can potentially "run up" to detonation if there is some confinement to reflect the combustion wave and the gas mixture is over $18.3 \%$ in air. Gas explosion experts generally agree that a gas deflagration, rather than a detonation, is the event that must be analyzed following a postulated gas release. 
It is interesting to note that there have been some reports of hydrogen fires and deflagrations in the recent past. Some of these events can be attributed to the lack of knowledge by those working with the gas in cylinders or pipe work, lack of awareness that hydrogen gas was present, or improper control of the hydrogen in process equipment. Other events are simply due to equipment failure in close proximity to an adequate ignition source. While there are still mishaps with hydrogen in various industries, it is clear that hydrogen can be handled safely if its physical properties are understood and appreciated by those using the gas, and if proper precautions are taken. The design codes and regulations for hydrogen will play an important role in ensuring that precautions are in place to protect users, workers, the public, and the environment from the consequences of hydrogen events, and that these precautions would be maintained by routine inspection and maintenance of facilities. Work with improving codes for hydrogen gas usage is an important area to introduce hydrogen fuel safely into consumer usage.

The codes and standards needed to regulate hydrogen usage are in a very early stage of development, much earlier than is the case for methane (natural gas) or gasoline. The natural gas vehicle section in the Uniform Fire Code has duplicated the National Fire Protection Association's standard on compressed natural gas vehicle safety into the code. Hydrogen codes and standards can be built upon from those in place for methane as a transportation fuel, since these are both lighter-than-air gases with low spark ignition energies for deflagration. Hydrogen codes and standards will have to take into account the unique physical, ignition and combustion characteristics of hydrogen gas.

Other areas of technology development that could be beneficial for increasing safety in hydrogen usage are design standardization so that fuel tank connections and refueling station connections are uniform; engineering analysis of nozzle connections to promote low wear, easily operated connections; low cost, accurate hydrogen gas detectors; and improved hydrogen fire detectors. The standardized fuel connections mean refueling without having to use an adapter, which would reduce mishandling and small leakage concerns. Connections that are easy to operate, seal securely and wear well would also reduce the occurrence of small hydrogen leaks during routine refueling. Hydrogen gas detectors would be needed to protect enclosed spaces, just as natural gas detectors are presently recommended in the Uniform Fire Code for repair garages and other buildings. Hydrogen fire detectors typically operate by sensing ultraviolet or infrared wavelengths, since hydrogen fires typically do not give off visible light. These fire detectors are advanced technology, are relatively expensive, and can be susceptible to false alarms.

Hydrogen is a technically promising fuel for transportation. Testing experiences thus far have been positive. In particular, the hydrogen and fuel cell technology combination promises quiet, low emission power for automobiles, buses, industrial forklift trucks, and other vehicles. 